DANMARKS GEOLOGISKE UNDERS ØGELSE - DGU SERIE B · NR. 12 MIL JØMINISTERIET · Geological Survey of Denmark - DGU SERIES B · No. 12

Diagenesis of the Zechstein Ca-2 carbonate from the Løgumkloster-1 well, Denmark

BY

NIELS STENTOFT

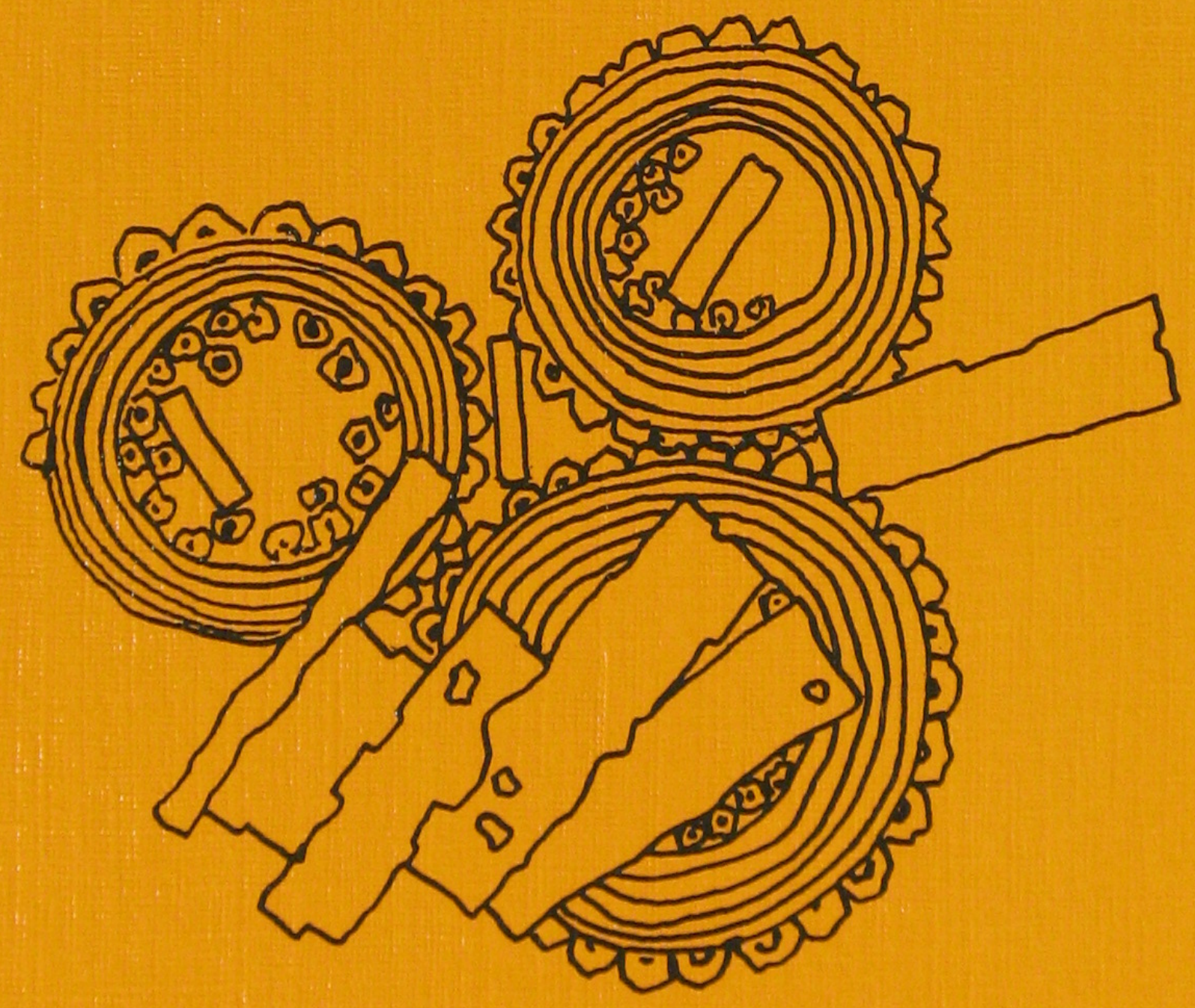

Danmarks Geologiske Undersøgelse · København 1990 


\section{Diagenesis of the Zechstein Ca-2 carbonate from the Løgumkloster-1 well, Denmark}

BY

NIELS STENTOFT 
Key words:

Zechstein, Carbonate,

Diagenesis, Permian, Denmark

Vignette:

Ooid grainstone with anhydrite replacement

DGU $\cdot$ Serie B $\cdot$ Nr. 12

ISBN 87-88640-48-5

ISSN 0901-0289

Oplag: 1000

Tryk: AiO Tryk as, Odense

Tegning: Helle Zetterwall

Foto: Peter Moors

Dato: $15-3-1990$

Niels Stentoft

Geological Survey of Denmark

Thoravej 8, DK-2400 Copenhagen NV, Denmark

Redaktion: Leif Banke Rasmussen

(C) Danmarks Geologiske Undersøgelse,

Thoravej 8, DK-2400 København NV.

I kommission hos: Geografforlaget ApS.

Ekspedition: Fruerhøjvej 43, 5464 Brenderup

Telefon: 64441683 


\section{Contents}

Abstract ............... 5

Introduction. .............. 6

Materials and methods .......... 8

Results .................. 9

Macroscopic core description ..... 9

Allochems and algal structures .... 11

Depositional environment........ 14

Rock fabric and pore geometry .... 14

On the diagenetic history ....... 21

Early lithification/dolomitization . 22

Recrystallization ........... 23

Leaching-phase I........... 23

Stylolitization............. 24

Precipitation of dolomite cement. 24

Leaching-phase II.......... 25

Precipitation and subsequent pseudomorphic alteration of gypsum (?) crystals . . . . . . 27

The precipitation of intercrystalline dolomite cement ...... 28

Anhydrite cementation/replace-

1

4

4

1

3

3

24

5

Celestine cementation/replacement.............. 31

Cementation/replacement by quartz .............. 31

Cementation/replacement by halite ............. 32

Precipitation and dissolution of dolomite (?)-rhombs....... 33

The introduction of oil ...... 33

The relationship between some of the diagenetic phases and the burial history ........... 33

A comparison between the diagenetic history of the Ca-2 rock of Løgumkloster-1 and that of the corresponding rock of Brøns-1 . 34

Discussion ............... 35

Synthesis................. 38

Acknowledgements ........... 40

References................. 41 


\section{Preface}

This paper summarizes part of a research project entitled "Diagenesis and porous system in Danish Zechstein carbonate reser- voirs". This project, partly financed by the EEC (contract No. EN3C/003-DK (MB)), extended from April 1986 to April 1989. 


\section{Abstract}

The carbonate unit $\mathrm{Ca}-2$ found in the $\mathrm{L} \emptyset$ gumkloster-1 well is located on the northern marginal carbonate platform of the North German Zechstein Basin. The ca. $43 \mathrm{~m}$ thick sequence includes former oncoidal/algal muds which were deposited in a relatively quiet lagoonal back-barrier environment, and ooidal carbonate sands, deposited in a rather agitated shoal environment.

The carbonate sediments of $\mathrm{Ca}-2$ have been subjected to a complex sequence of diagenetic events. However, the present porosity/permeability, and thus the reservoir quality of the rocks, is primarily linked to four events: two leaching phases, a phase of chemical compaction, and a late anhydritization. The first phase of leaching created mouldic porosity. The last phase of leaching was important as it resulted in a widening of the preexisting pores and fractures and thereby facilitated percolation of sulphate solutions causing the late anhydritization, which considerably reduced the porosity/ permeability of the rock.

The present pore geometry of the rock is complex. In the oolitic intervals the intraand interooidal porosity types are the most widespread. In the oncolitic/algal intervals intra- and interoncoidal porosity and vuggy porosity are often combined with intercrystalline porosity.

The corresponding $\mathrm{Ca}-2$ rock in the Brøns-1 well, situated ca. $20 \mathrm{~km}$ northwest of the Løgumkloster-1 well, was subjected to the same post-depositional evolution. Comparison with the diagenesis of the upper part of the Ca-la formation in the Aabenraa-1 well and the Ca-1 formation of the Varnæs-1 well also shows close similarity in the diagenetic evolution. 


\section{Introduction}

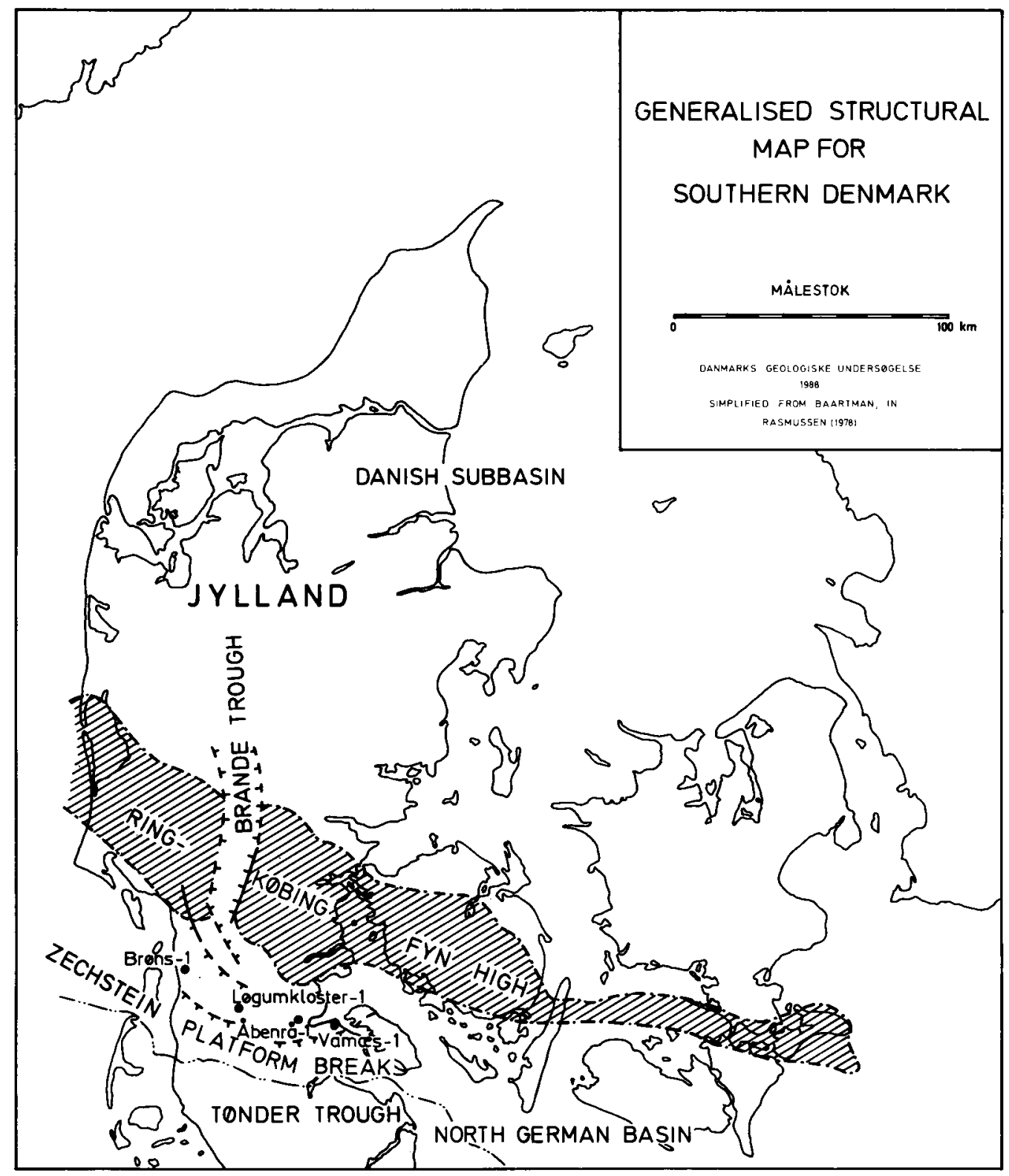

Fig. 1: Location of the studied wells in southern Jylland, Denmark. 
The Løgumkloster-1 well is located in Southern Jylland, Denmark (fig. 1). During Zechstein time this area was situated along the southern slope of the Ringkøbing-Fyn High, which formed the northern margin of the North German Zechstein Basin. The northern margin of a fault bounded depression, the Tønder Trough, divided the area into a northern platform and a southern basin (fig. 1; Baartman, in Rasmussen, 1978; Stemmerik et al., 1987).

The Zechstein sequence in Southern Jylland consists of cyclic repetitions of carbonate, anhydrite and salt. In the platform area where the deposits are ca. $470-$ ca. $530 \mathrm{~m}$ in thickness, anhydrite and carbonate dominate. Southward, towards the interior of the basin, the salt intervals thicken considerably and the interbedded carbonate and anhydrite intervals become much thinner. The deposits of the interior of the basin exceed $1000 \mathrm{~m}$ or more in thickness (Clark \& Tallbacka, 1980; Stemmerik et al., 1987).

In the Løgumkloster-1 well, which is situated in the platform area (fig. 1), the Zechstein sequence is $531 \mathrm{~m}$ in thickness. In accordance with the stratigraphical classification of Richter-Bernburg (1955) the sequence can be subdivided into at least three sedimentary cycles: $\mathrm{Z} 1, \mathrm{Z} 2$ and $\mathrm{Z} 3$ (fig. 2). Clark \& Tallbacka (1980) divided the Zechstein of Southern Jylland into five cycles (Zechstein Group 1-5 corresponding to Z1-Z5 of Richter-Bernburg). However, the cyclicity of the uppermost part of the Zechstein of Løgumkloster-1 is not clearly developed, for which reason a further subdivision has not been carried out here. The $41 \mathrm{~m}$ thick carbonate sequence studied in this paper, the Ca- 2 unit, corresponds to the Hauptdolomit of the Z2 carbonate (Stassfurt-Serie) of Germany.

The present paper outlines some of the

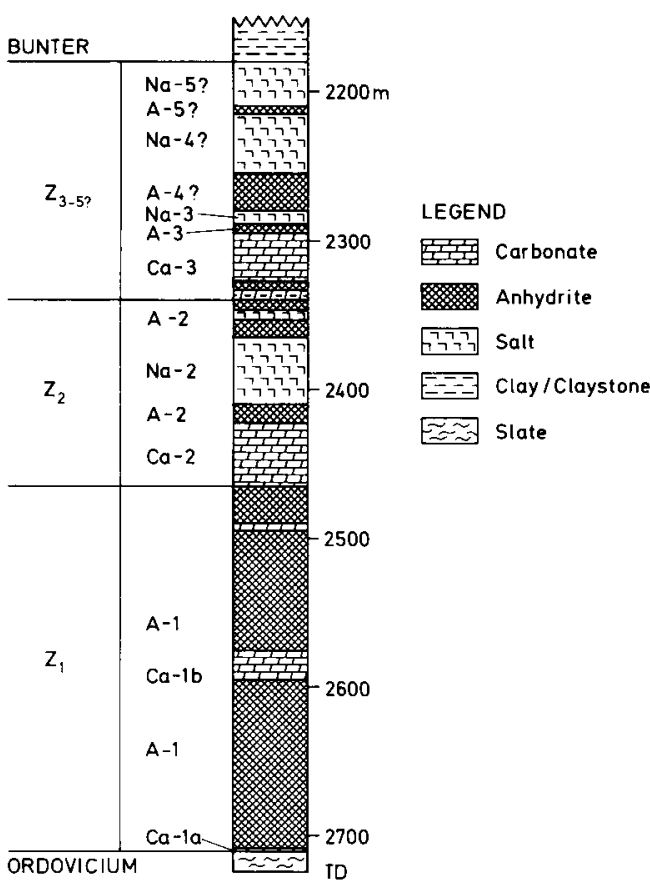

Fig. 2: Lithology and stratigraphy of the Zechstein sequence in the Løgumkloster-1 well. Based on mud and wireline logs. The classification of Richter-Bernburg (1955) is used.

factors that have affected the reservoir quality of the $\mathrm{Ca}-2$ unit. The main topics be considered are: the sedimentology, the palaeontology and, most important, the diagenesis.

To reveal the history of the rock, its original composition must be known and a relative timing of the post depositional events must be established. These events include physico-chemical alterations (fractures, solution seams, and stylolites), transformations (recrystallization and substitution) and removal/supply of material. The sequence of events is tentatively set in relation to the local burial history. 


\section{Materials and methods}

The available cores representing the $\mathrm{Ca}-2$ formation of the Løgumkloster-1 well are ca. $41 \mathrm{~m}$ long, extending from 2424 to ca. $2465 \mathrm{~m}$ b.RT. Most core material was slabbed prior to the investigation.

The microscopic investigation is based on 118 thin sections. The material was taken from plugs. Half of each thin section was stained with alizarin red-S in order to facilitate the distinction between calcite and dolomite (Dickson, 1965). As the allochems often have been partly obliterated during the diagenesis of the rocks no point counting has been attempted. Instead, the percentage of the components was estimated semiquantitatively by means of comparison charts (Bosellini, in Flügel, 1978). The term abundant means more than $10 \%$, common means $1-10 \%$ and rare is less than $1 \%$.

Porosity, air permeability, and grain density were measured on each plug.

The classification of the rock follows Dunham (1962) and Randazzo \& Zachos (1984). In the description of cements the nomenclature of Bathurst (1976) is used. The crystal size scale is from Folk (1965):

ECxn Extremely coarsely crystalline $>4 \mathrm{~mm}$ VCxn Very coarsely crystalline $1-4 \mathrm{~mm}$ Cxn Coarsely crystalline $\quad 0.25-1 \mathrm{~mm}$ Mxn Medium crystalline $\quad 62-250 \mu \mathrm{m}$ Fxn Finely crystalline $\quad 16-62 \mu \mathrm{m}$ VFxn Very finely crystalline $\quad 4-16 \mu \mathrm{m}$ Axn Aphanocrystalline $\quad<4 \mu \mathrm{m}$ 


\section{Results}

\section{Macroscopic core description}

A summary of the results from the core descriptions are depicted in fig. 3 .

The Ca- 2 carbonate is a well consolidated, white to light grey dolomite, which is faintly to strongly cemented or replaced by a light greyish blue anhydrite. Because of the varying content of anhydrite the rock has often a mottled/turbated appearance. In places where the rock is especially anhydritized (cf. the lithology column in fig. 3) it has a marble-like appearance as the residual dolomite forms irregular outlined strings, bands and diffuse amoeboid specks.

According to the carbonate texture the $\mathrm{Ca}-2$ sequence can be divided into three subunits (subunit I, II and III of fig. 3) with interval boundaries at ca. $2432 \mathrm{~m}$ and ca. $2443 \mathrm{~m}$ respectively. The carbonate of subunit II is an oolitic grain- to packstone. In subunits I and III it is dominantly an oncolitic/oolitic wacke- to grainstone, but oolitic/oncolitic mudstone is locally widespread. In the latter the ooids/oncoids seem to have been largely erased by diagenesis. The rock of both units I and III is interbedded with several $\mathrm{mm}$ - to $\mathrm{cm}$-scale layers of wavy laminated boundstone.

Indistinct lamination is locally observed in the oncolitic/oolitic carbonate. Cross lamination is restricted to subunit II.

There is an inverse proportionality between the visible porosity and the content of anhydrite. Apart from the lowermost few metres the rock has $5-20 \%$ visible porosity in the tiny inter- and intraooidal/oncoidal pores. Further, there are many isolated mmscale solution vugs (fig. 3). Many of the fractures have obviously been widened by

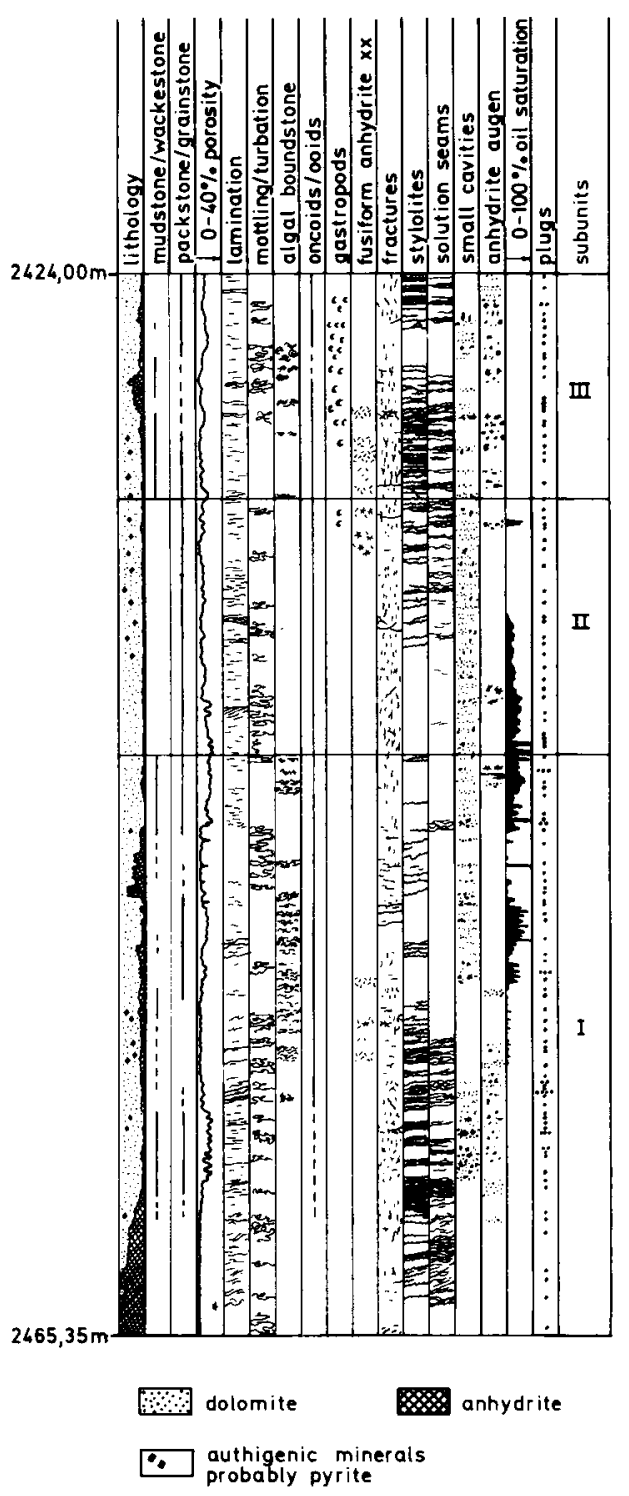

Fig. 3: Graphic core log of the Ca-2 unit in the Løgumkloster-1 well, based on macroscopic observations. 
leaching. The algal boundstone is commonly very vuggy. The vugs, which mimic the algal laminae, are up to a few $\mathrm{mm}$ long in the laminar plane. They resemble the planar-type bird's-eye voids described by Shinn (1983, p. 184).

All the most conspicuous fractures and stylolites are recorded in fig. 3 . The vast majority of the fractures are at almost right angles to bedding. They are short, often a few $\mathrm{cm}$, and many of them terminate at a stylolite seam, be it from below or above.
The separation between the fracture faces often increases towards the seams.

Generally the stylolites are "thin", meandering hairlines in cross section. They are dark-coloured, probably organic-rich drapes, and they have maximum amplitudes of ca. $1 \mathrm{~mm}$. They are mostly rather unimpressive and some of them disappear laterally. Stylolites with amplitudes up to ca. $1 / 2 \mathrm{~cm}$ are only present in the upper part of subunit III and the lower part of subunit I. Most of the stylolite planes are parallel and
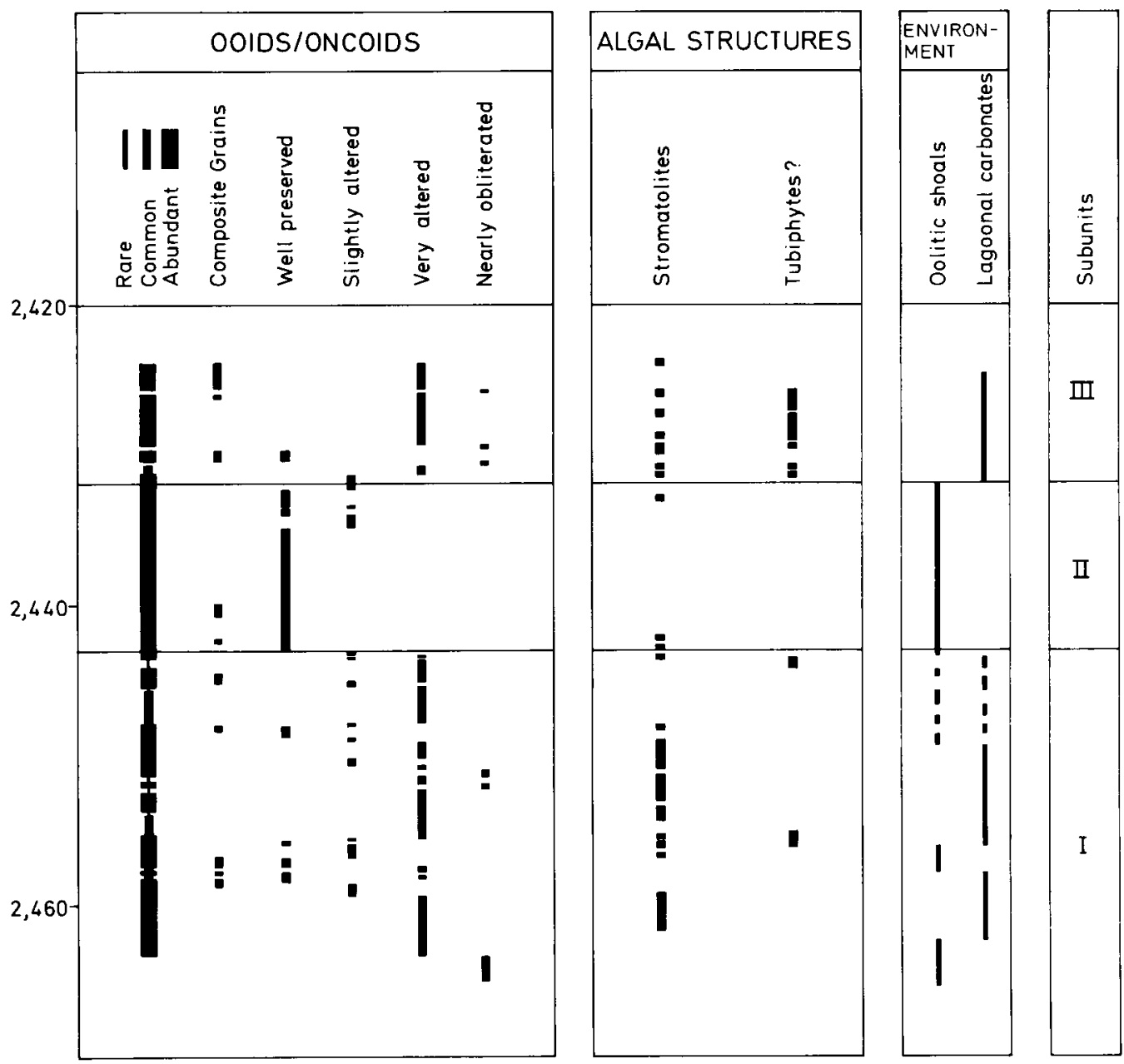

Fig. 4: The contents of ooids/oncoids and algal structures in the Ca-2 carbonates, the Løgumkloster-1 well (from the study of thin sections) with a statement on the textural/morphological preservation of the ooids/oncoids. The suggested environmental subdivision of the unit is shown to the right. 


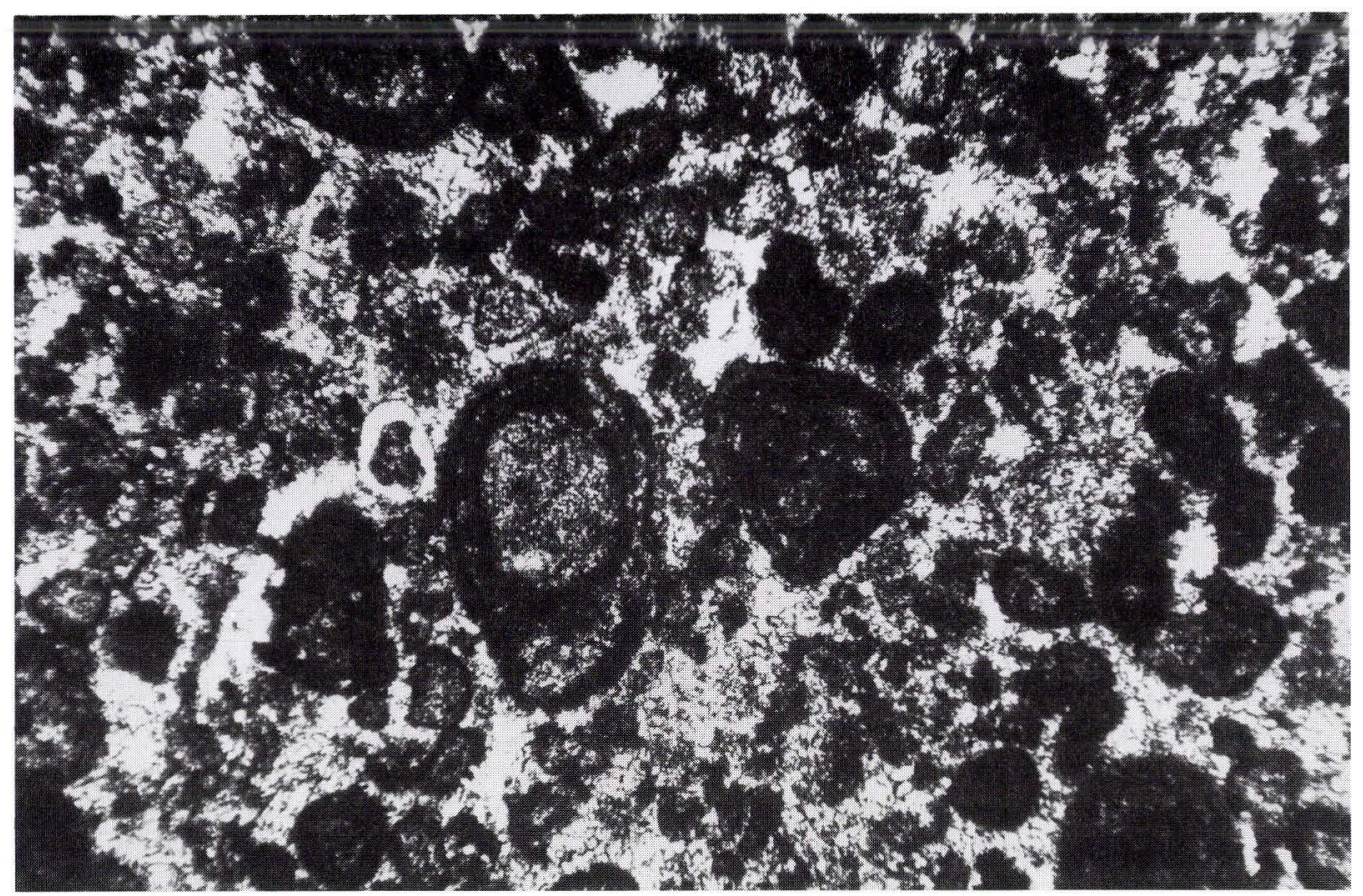

Fig. 5: Oncoids from Subunit III, mostly preserved as ringshaped Axn to VFxn dolomite. The concentric laminar structure is still present in a few of the oncoids. The rock is here cemented/partly replaced by anhydrite.

Width of view is $2.2 \mathrm{~mm}$ (Sample 1783 at $2429.8 \mathrm{~m}$ ).

horizontal, but locally they anastomose (fig. $3)$.

Solution seams are most frequent in the lower half of subunit I (fig. 3) where they locally form a "flaser-stone". In between the anastomosing flasers the dolostone forms longish, diffuse specks, giving the rock a pseudo-nodular appearance.

The anhydrite occurs both as a "passive" cement, filling the tiny pores, the fractures and the solution vugs, and as a dolomite replacement. Except for the intervals, where the rock is so anhydrite-rich that only "rags" and specks of the original dolomite are left, the replacing anhydrite mostly constitutes scattered specks or augen (fig. 3.). These augen vary in maximum cross section from less than $1 \mathrm{~mm}$ to a few $\mathrm{cm}$. They are often very irregular in outline and sometimes distinctly amoeboid. The more or less indistinct boundaries to the surrounding dolomite indicate their replacive origin.
A special form of augen is the socalled "knife stabs" recorded in two short intervals (fig. 3). The "knife stabs" are up to $3 \mathrm{~mm}$ long, fusiform anhydrite crystals which are found scattered in the dolostone with their long axes randomly orientated. Locally the crystals form star-like aggregates which resemble rosettes of gypsum.

\section{Allochems and algal structures}

The coated grains, which have been characterized as ooids and oncoids in the core description, are abundant and rockforming grains in the greater part of the sequence (fig. 4). All grades of preservation are found (by study of thin sections, cf. fig. 4). Generally the coated grains of subunit II are texturally well preserved whereas the grains of subunit I and III are very altered by diagenesis, in places almost obliterated. The 


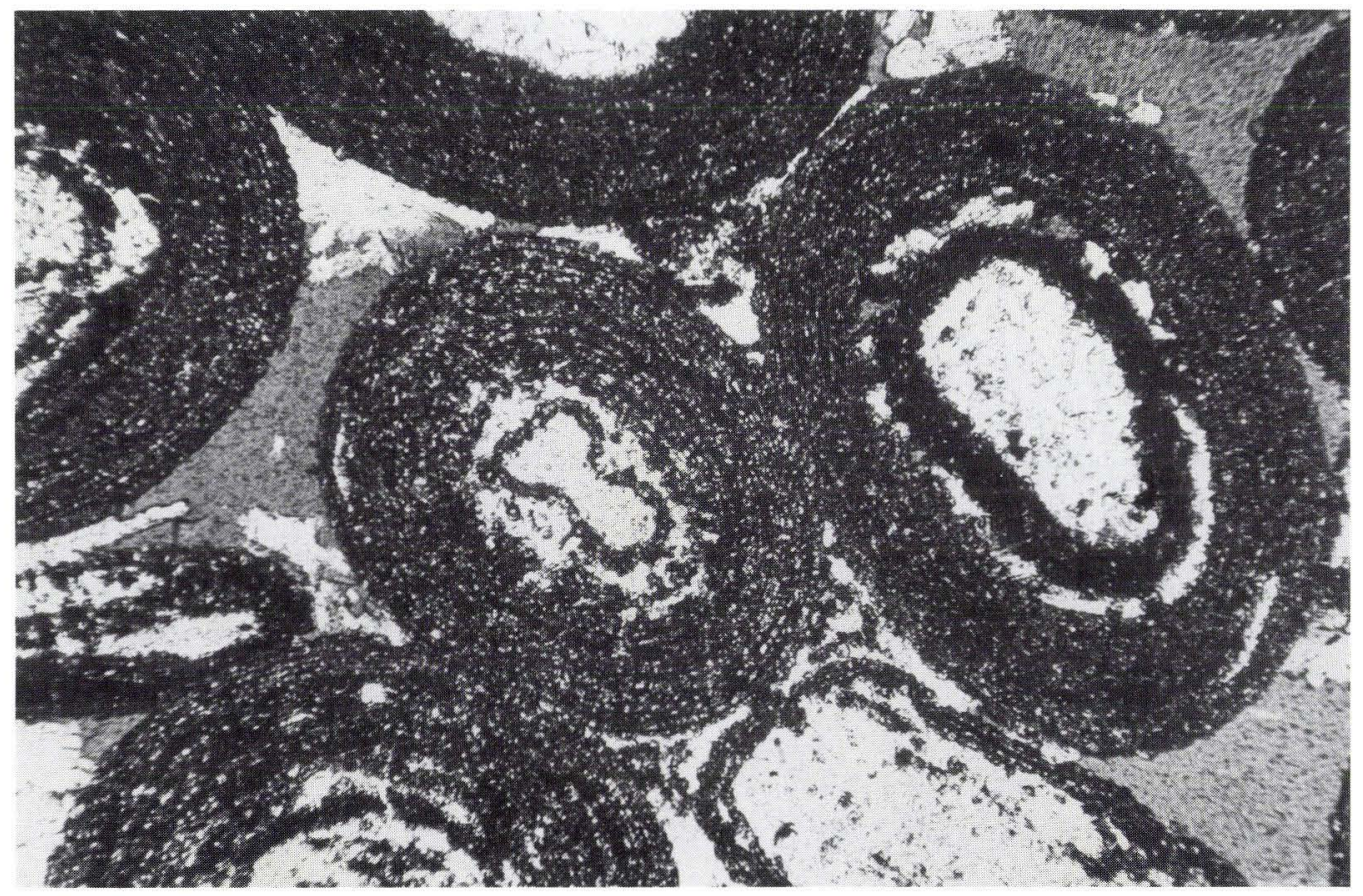

Fig. 6: Ooids from subunit II. The algal-like concentric structures are rather well preserved. The hollow ooids, now filled in with anhydrite, consist of a VFxn to Fxn dolomite. In the ooid in the middle of the picture a »loose « lamina is seen, which consists of Fxn, hollow subhedrals of dolomite with intracrystalline pores.

Width of view is $2.2 \mathrm{~mm}$ (Sample 1756, depth $2441.4 \mathrm{~m}$ ).

well preserved grains are rather dim in thin section. No pseudo-uniaxial cross is seen with crossed nicols (compare the "Mikritische Ooide" of Flügel, 1978 p. 119). This indicates that they are aphanocrystalline, and are built up of distinct laminae without preferred arrangement of the crystals.

The coated grains vary a great deal both morphologically and in size down the sequence. In subunit III the variation in size is considerable (cf. fig. 5), ranging from a few teens of $\mu \mathrm{m}$ to a few $\mathrm{mm}$ in cross section. They are subrounded to well rounded (according to the roundness chart of Pettijohn, 1957); spherical grains are seldom seen. The greatest grains are often longish, leaf-like when seen in cross section, having their long axis in the horizontal plane. These coated grains are built up of fewer and more irregularly shaped laminae than the coated grains of subunit II. In subunit II the variation in size of the coated grains is small. Mostly they range from 500 to $800 \mu \mathrm{m}$ in cross section, and as distinct from the coated grains of subunit III they are well rounded to perfectly spherical in outline. Generally they consist of many regular laminae. Some typical coated grains of subunit II are shown in fig. 6. Both types of coated grains, of subunit III and II respectively, are found in subunit I. Well rounded to spherical grains of the type of subunit II are found in several short intervals in the top of the subunit between $2443 \mathrm{~m}$ and $2449 \mathrm{~m}$, and in an interval further down, between ca. $2456 \mathrm{~m}$ and $24571 / 2 \mathrm{~m}$. The nearly obliterated grains of the lowermost part of subunit I, from ca. $2463 \mathrm{~m}$ and downwards to the underlying anhydrite (A-1), belong to the same category. In the remaining part of sub- 
unit I the great majority of the coated grains resemble those of subunit III having the same variation in morphology and size.

Composite coated grains are found in all subunits (cf. fig. 4) but they are most common in subunits I and III. Foreign nuclei, around which the carbonate layers are arranged in a concentric manner in some ooids (cf. the definition of ooids in Flügel, 1978 p. 115), have never been seen in the coated grains of $\mathrm{Ca}-2$.

In accordance with the classification of coated grains stated by Richter (1983 a and b) the coated grains of the $\mathrm{Ca}-2$ unit have been subdivided purely descriptively as ooids and oncoids. A genetic classification (e.g. Herrmann, 1956; Peryt, 1983) has not been attempted here. The more regular grains found in subunit II and in some intervals in subunit I are called ooids, the more irregular grains found in subunit III and in the greater part of subunit I oncoids.

The distribution of the interbedded stro- matolites is shown in fig. 4 (cf. the algal boundstone of fig. 3). They are practically absent in the oolitic subunit II. Generally, the single stromatolite comprises a wavy band a few $\mathrm{mm}$ thick, when seen in cross section. The stromatolites have the same microstructure as the surrounding ooids/oncoids.

Algal-like structures having some resemblance to the alga Tubiphytes obscurus described by Johnson (1963) occur scattered in subunit III and in oncolitic intervals of subunit I (fig. 4 and 7). Tubiphytes has been classed as a foraminifera by some workers (e.g. Peryt \& Peryt, 1975; Füchtbauer, 1980).

Gastropods are found with certainty only in subunit III and in the uppermost part of subunit II (fig. 3). They are rather common in the interval between $2425 \mathrm{~m}$ and $2430 \mathrm{~m}$. Only one genus seems to be present, but it has not been identified. The low-spired tests are up to $1 / 2 \mathrm{~cm}$ in cross section.

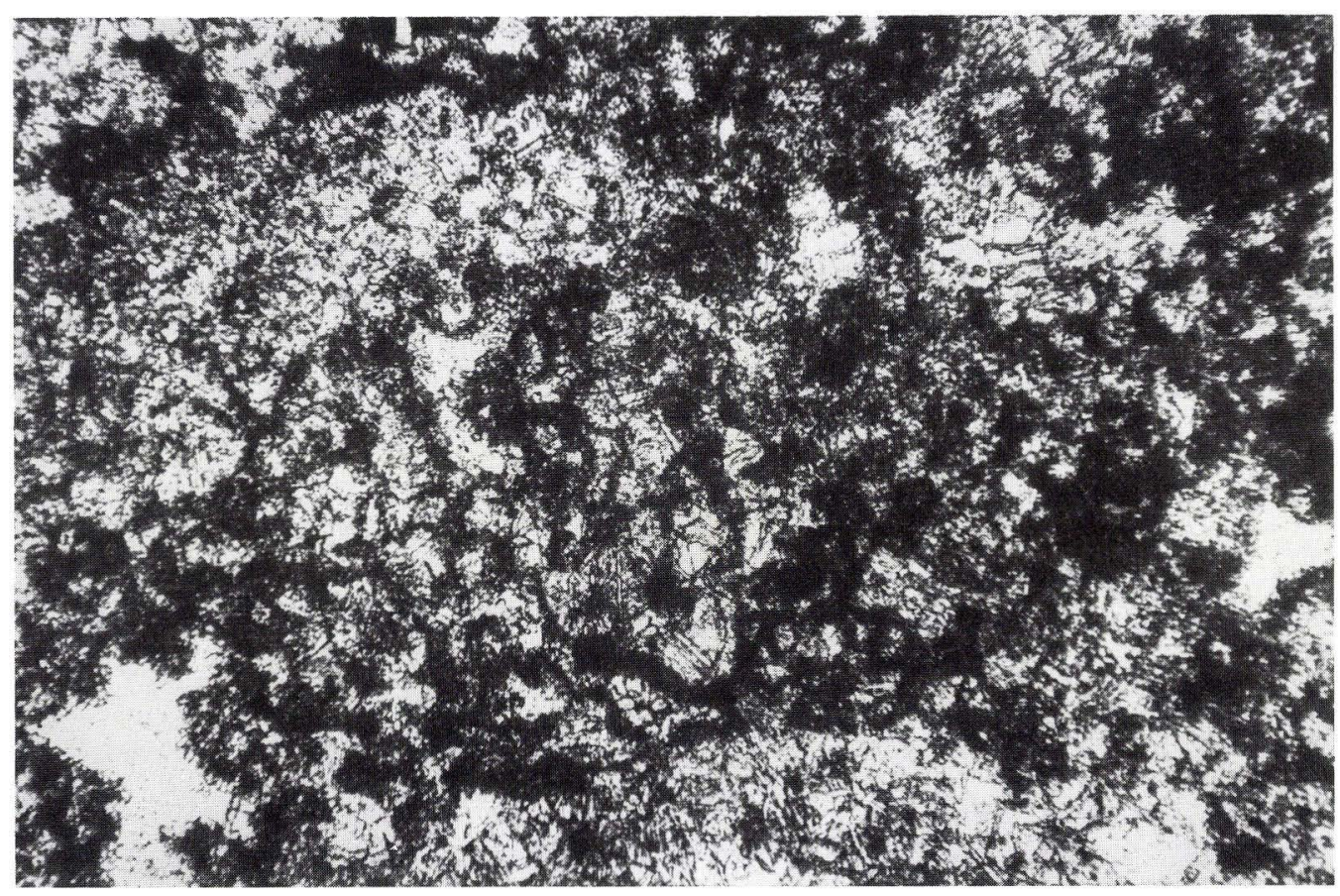

Fig. 7: Algal like structures that have some resemblance to Tubiphytes.

Width of view is $2.2 \mathrm{~mm}$. (Sample 1792 at $2427.4 \mathrm{~m}$ ). 
Ostracods are restricted to subunit III. However, some indistinct structures in subunit I may be almost obliterated ostracod shells.

Foraminifera are observed in subunit III and in the upper half of subunit II. The specimens from the former unit are Nodosaria like, those from the latter belong to the genus Glomospira.

\section{Depositional environment}

The classification of the coated grains into ooids and oncoids given above says nothing about the role of microorganisms in the ooid/oncoid formation; it is not a genetic classification like that given by Peryt (1983). Many workers have discussed how far ooids are the product of algal and/or bacterial activity (see Bathurst, 1976, chapter 7; Richter, 1983 b, p. 74). The well preserved coated grains, both ooids and oncoids, of unit Ca- 2 of the Løgumkloster-1 well consist of micritic layers of randomly oriented dolomite crystals. They may have developed from micritic $\mathrm{Mg}$-calcitic or aragonitic coated grains. According to Flügel (1978, p. 97) a micritic ooid is either a micritized (cf. Bathurst, 1976) "Normalooide" or it is formed primarily by sediment-trapping blue-green algae. If the coated grains of Ca-2 were completely micritized in connection with the activity of some boring cyanobacteria or algae it is inconceivable to the writer why the concentric laminae are so distinct. Whether the formation of the grains has been influenced by the activity of microorganisms is difficult to say. No delicate technique has been used here to reveal algal or bacterial structures (cf. Bathurst, 1976, p. 297). However, no algal filaments have ever been observed in the thin sections by use of light microscope. Consequently, under the present circumstances, texturally the coated grains of $\mathrm{Ca}-2$ cannot support environmental interpretations.

However, the morphology of the coated grains may give some idea of the deposi- tional environment. According to Flügel (1978) it is possible from the morphology of ooids to separate ooids formed in low energy environment from "normal" ooids formed in high energy environment. The oncoids of subunit I and III in the Ca-2 sequence of the Løgumkloster-1 well fulfill many of the criteria of autochthonous ooids (Flügel, 1978, p. 125) formed in a low energy environment, e.g. a lagoon or in greater depth of water than "normal" ooids. The presence of the wavy stromatolites in the oncolitic intervals may support the assumption that the wave action was rather slight. The stromatolitic structures are probably algal in origin as suggested by the presence of the planar-type vugs (cf. the macroscopic core description). According to Logan et al. (1964, p. 77) similar algal structures may be found in intertidal mud-flat environment "mainly in the protected locations of reentrant bays and behind barrier islands and ridges where wave action is usually slight". For that reason the oncoidal carbonates are suggested to have been deposited in a lagoonal environment in depths of water ranging from shallow subtidal to upper intertidal (fig. 4).

The better rounded and better sorted ooids of subunits I and II of the Ca-2 sequence were pobably formed in a high energy environment (Bathurst, 1976; Flügel, 1978) as confirmed by the presence of crosslaminations in subunit II (fig. 3). The ooids may have formed shoals or bar systems (fig. 4).

\section{Rock fabric and pore geometry}

The coated grains have been responsible to a high degree for the present rock fabric and pore geometry. The stromatolitic structures have only locally directed the configuration of vugs (the planar-type vugs). Because of leaching, an interooidal/-oncoidal and intraooidal/-oncoidal (mouldic) porosity is formed (fig. 6). Some primary intergranular porosity may have been present, especially 

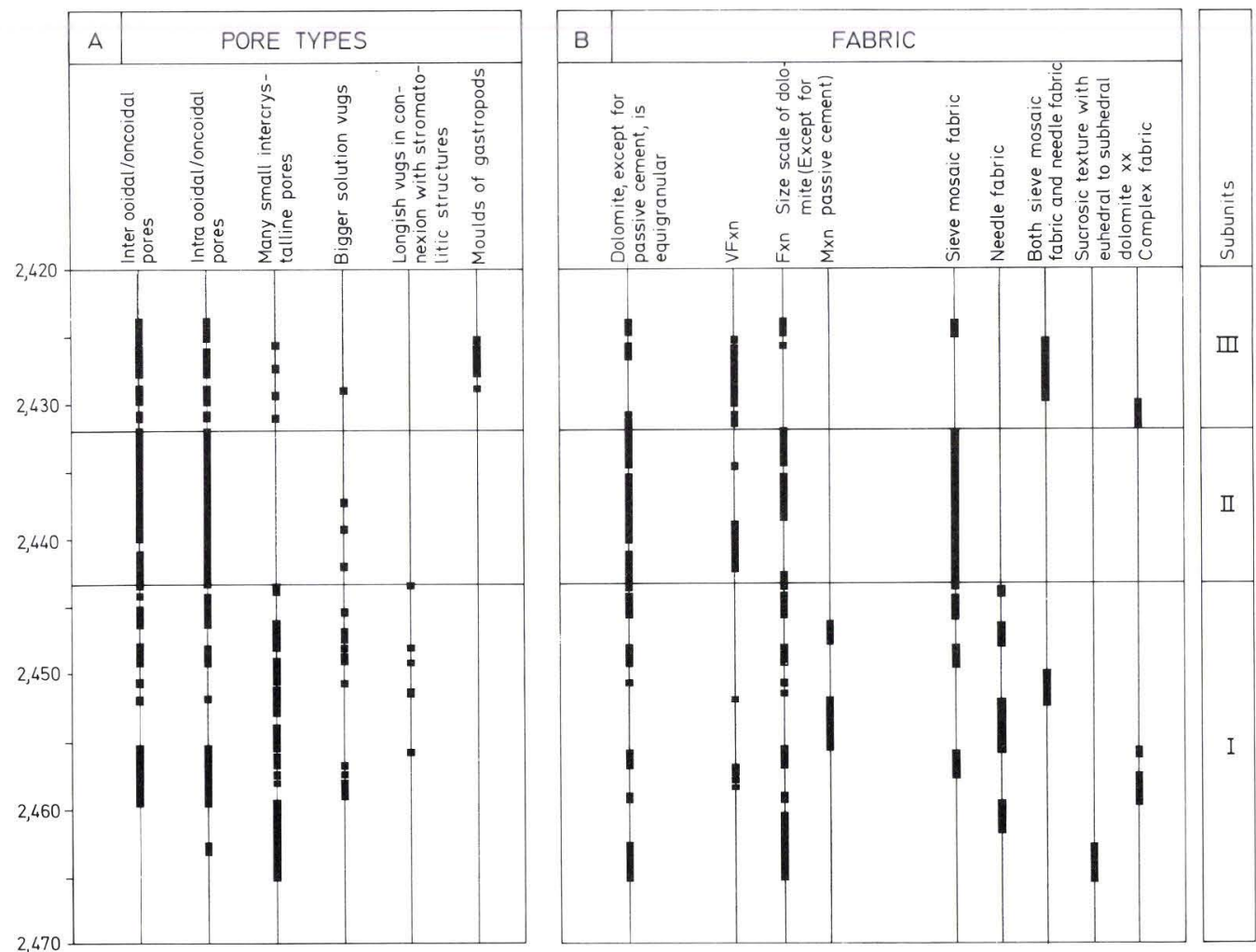

Fig. 8: The distribution of the most important pore types and the rock fabrics in the Ca-2 unit, the Løgumkloster-1 well, based on the study of thin sections.

in the oolitic rock intervals. Generally the rock has developed a sieve fabric. Because of a recrystallization, the carbonate of most of the oncoids/ooids themselves consists of ca. $30 \mu \mathrm{m}$ large interlocking crystals. As a result, a Fxn, xenotopic, sieve mosaic fabric, sensu Randazzo \& Zachos (1984), is widespread, especially in the oolitic intervals (fig. 8).

The sieve mosaic fabric is most poorly developed in the oncolitic/algal intervals. This is due to the presence of a more or less well developed intercrystalline porosity. Consequently, the pore geometry of the rocks is here a combination of both intra-/ inter-granular, vuggy and intercrystalline porosity. In places the intercrystalline porosity is dominant.

In the intervals with intercrystalline porosity some of the dolomite crystals consist of small, usually about $100 \mu \mathrm{m}$ long, lath to needle shaped cement crystals, probably pseudomorphs from gypsum. They are often overgrown by a relatively clearer dolomite cement in optical continuity with the needles (fig. 11 and 12). In areas rich in needles where the original oncoidal dolomite has been strongly attacked by leaching, the rock shows a needle-fabric that is a loose, open felted network of needles. The distribution of that special type of cement in the Ca-2 column is shown in fig. 9.

In the lowermost part of subunit I the intercrystalline porosity is connected with the presence of ca. $30 \mu \mathrm{m}$ large sub- to euhedral rhombohedra of dolomite. The rock has here almost a sucrosic texture. However, because of a marked cementation by anhydrite the porosity and permeability are low (fig. 10). The single sub- to euhedrale 


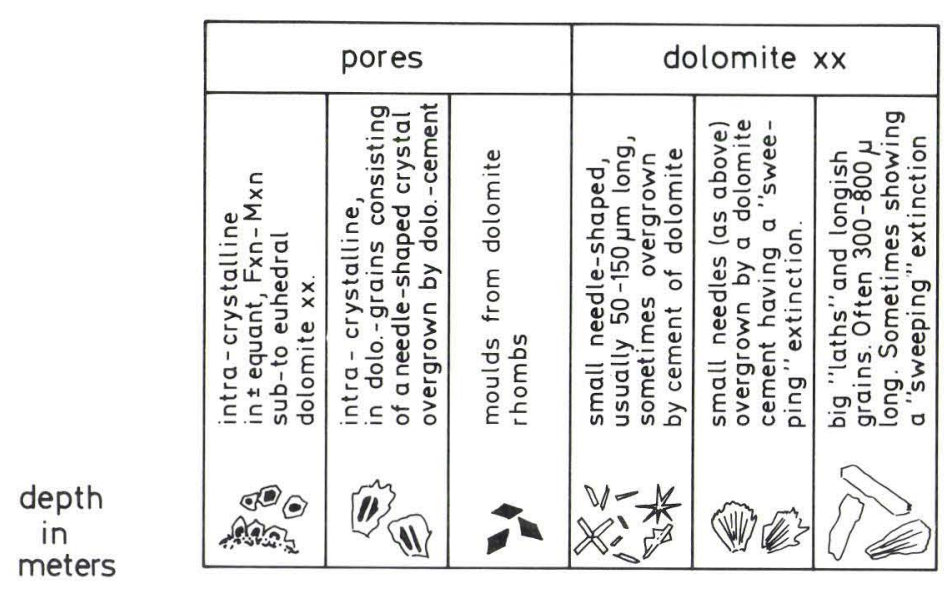

Fig. 9: The distribution of some particular types of porosity and dolomite crystals in the Ca-2 unit, the Løgumkloster-1 well based on the study of thin sections.

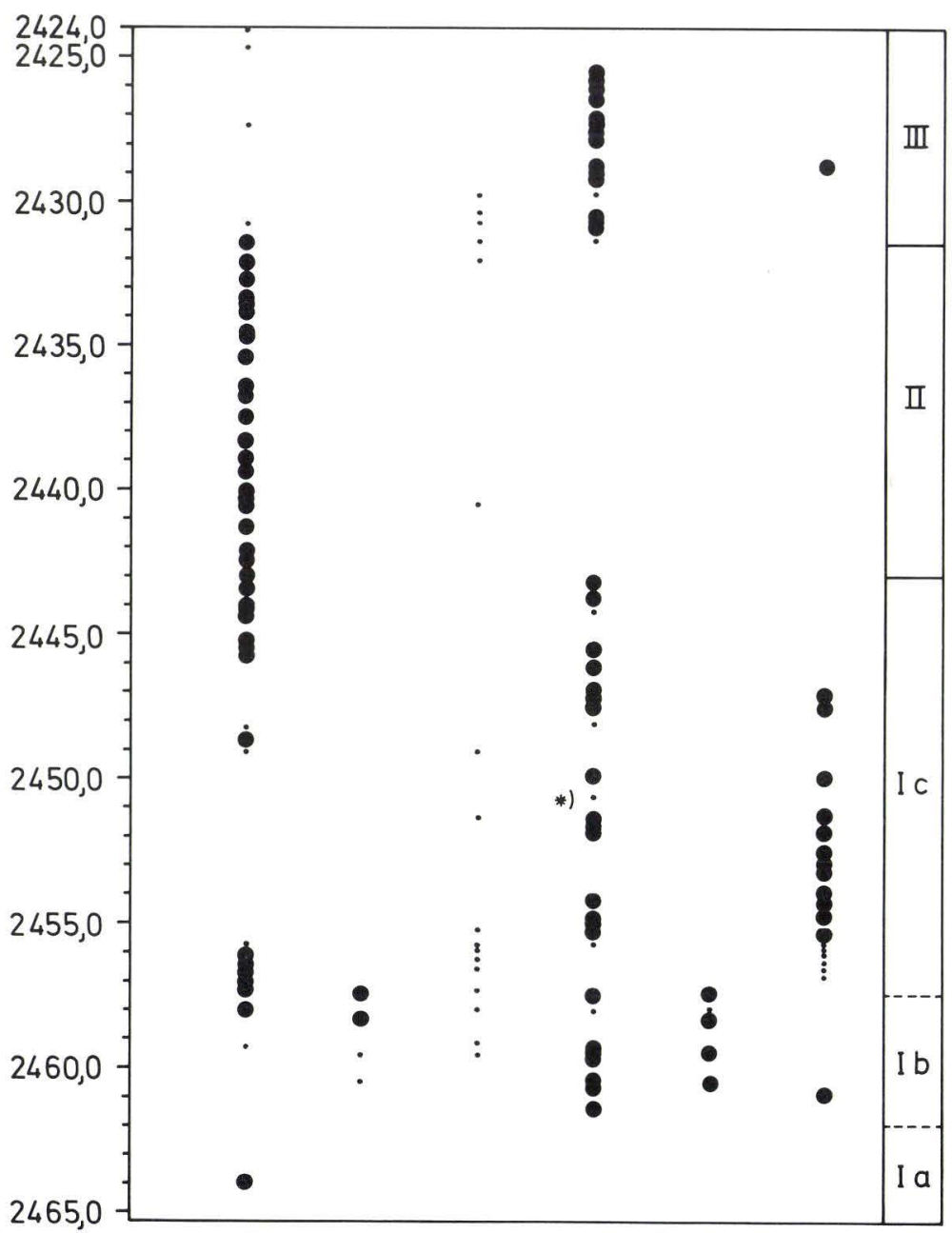

*) moulds of a needle-shaped Crystal inside a few oncoids

- common or abundant $\quad$ = not common, or rare 


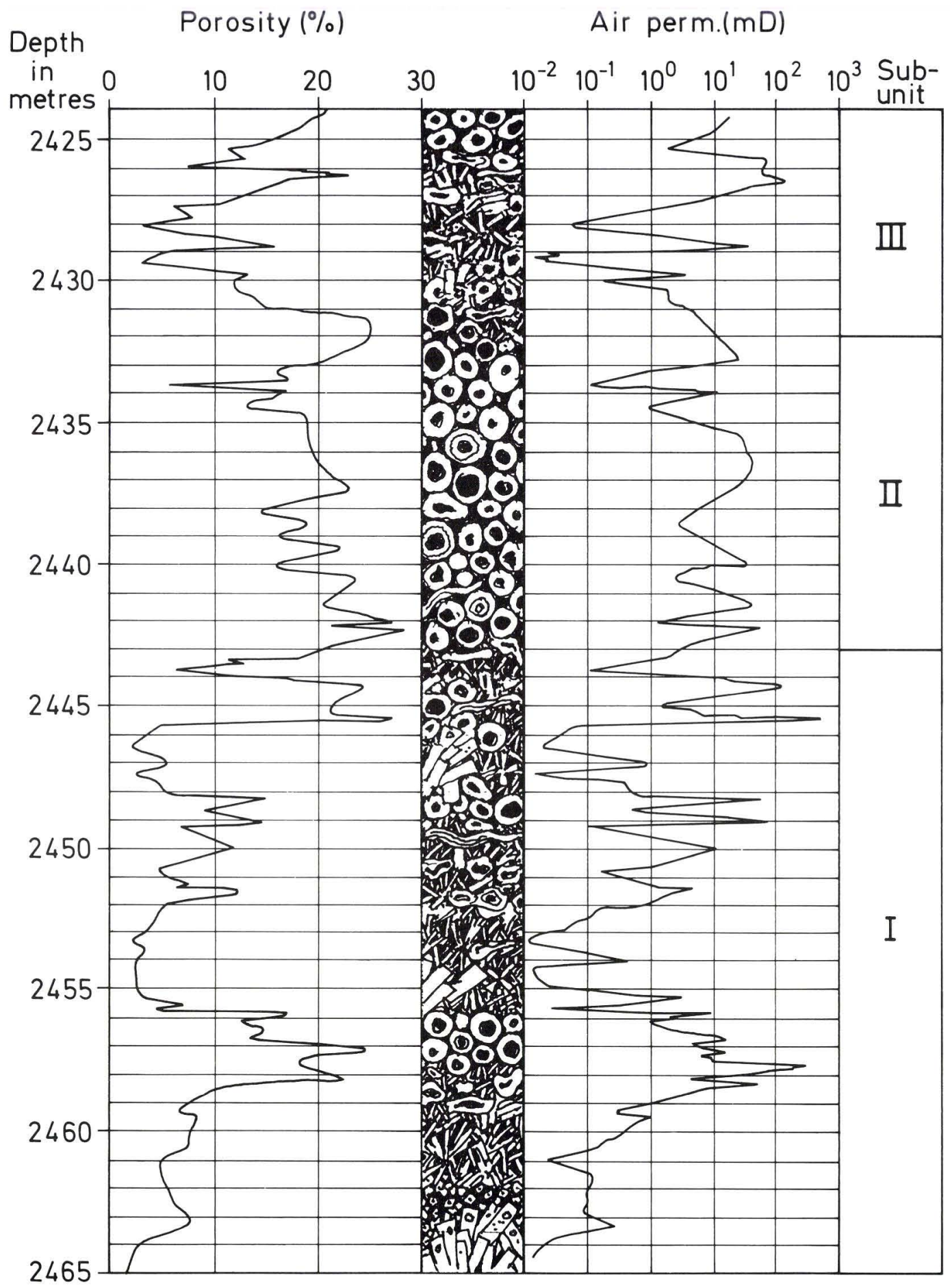

Fig. 10: The pore geometry in the carbonate rocks from the Ca-2 unit, in the Løgumkloster-1 well, depicted together with the porosity and air permeability curves. 
crystals are hardly distinguishable from the dolomite cement crystals precipitated higher up in the $\mathrm{Ca}-2$ sequence inside the ooids previously hollowed out by leaching. Like the latter, the innermost and oldest part of the crystals is often dissolved, giving an intracrystalline porosity.

Intracrystalline porosity (fig. 9) is rather conspicuous, especially in the oolitic intervals. However, these tiny pores do not affect the quality of the reservoir as expressed by porosity and permeability, because they are effectively shielded from the surrounding pores. As mentioned above, these pores are found inside subhedral dolomite cement crystals (Fxn mostly), precipitated inside and around the ooids previously attacked by leaching (fig. 13). For some reason the innermost, oldest part of the crystals has been dissolved during a second phase of leaching.

The pore cavities, both inside and around the coated grains, have in many places been partly filled in by anhydrite. Even in the faintly to moderately anhydrite cemented rocks of subunit II, which have a rather high porosity (ca. $20 \%$ ), air permeabilities of only a few $\mathrm{mD}$ are found because the anhydrite tends to block the pore throats (fig. 6 and 10). Besides anhydrite a stubby dolomite cement, which in places has grown out from the surfaces of the coated grains as isopachous rinds, has also caused some decrease of the permeability (fig. 14).

Fracturing would certainly increase the permeability, but most of the many short, mostly vertically faced fractures (see fig. 3) have been more or less filled by anhydrite cement.

Although the entire $\mathrm{Ca}-2$ interval is rather rich in stylolites (fig. 3) these levels of pressure-solution have probably not exerted an essential influence on the vertical flow of

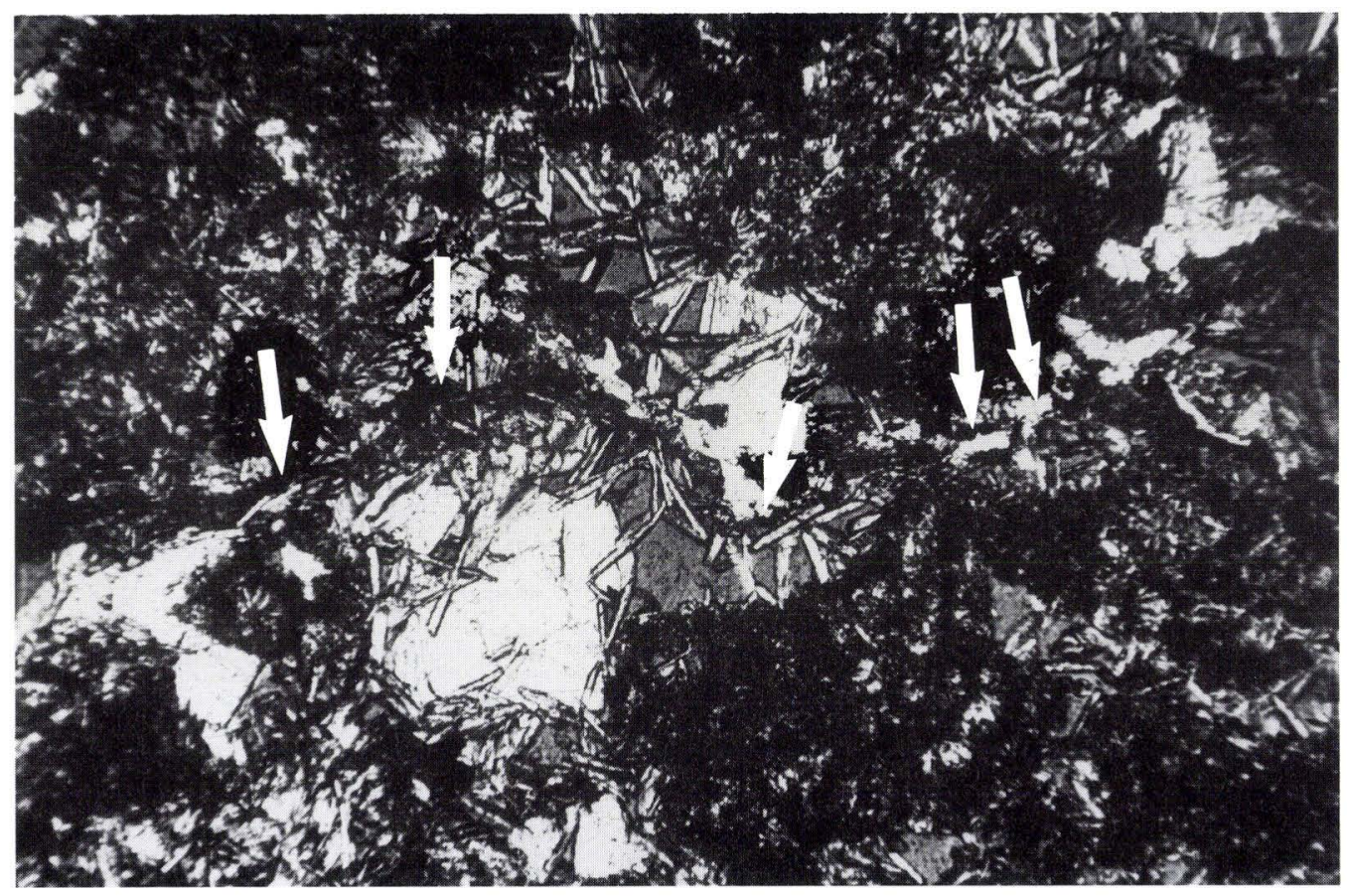

Fig. 11: A stylolite, which has been nearly completely obliterated, only a »string of pearls (arrows) of pyrite is left. Leaching took place after the formation of the seam. The small cavities formed by the leaching were later partly filled with needle cement. Stil later a scattered anhydrite cement (light coloured) was precipitated.

Width of view is $2.2 \mathrm{~mm}$ (sample 1797, depth: $2426.3 \mathrm{~m}$ ). 


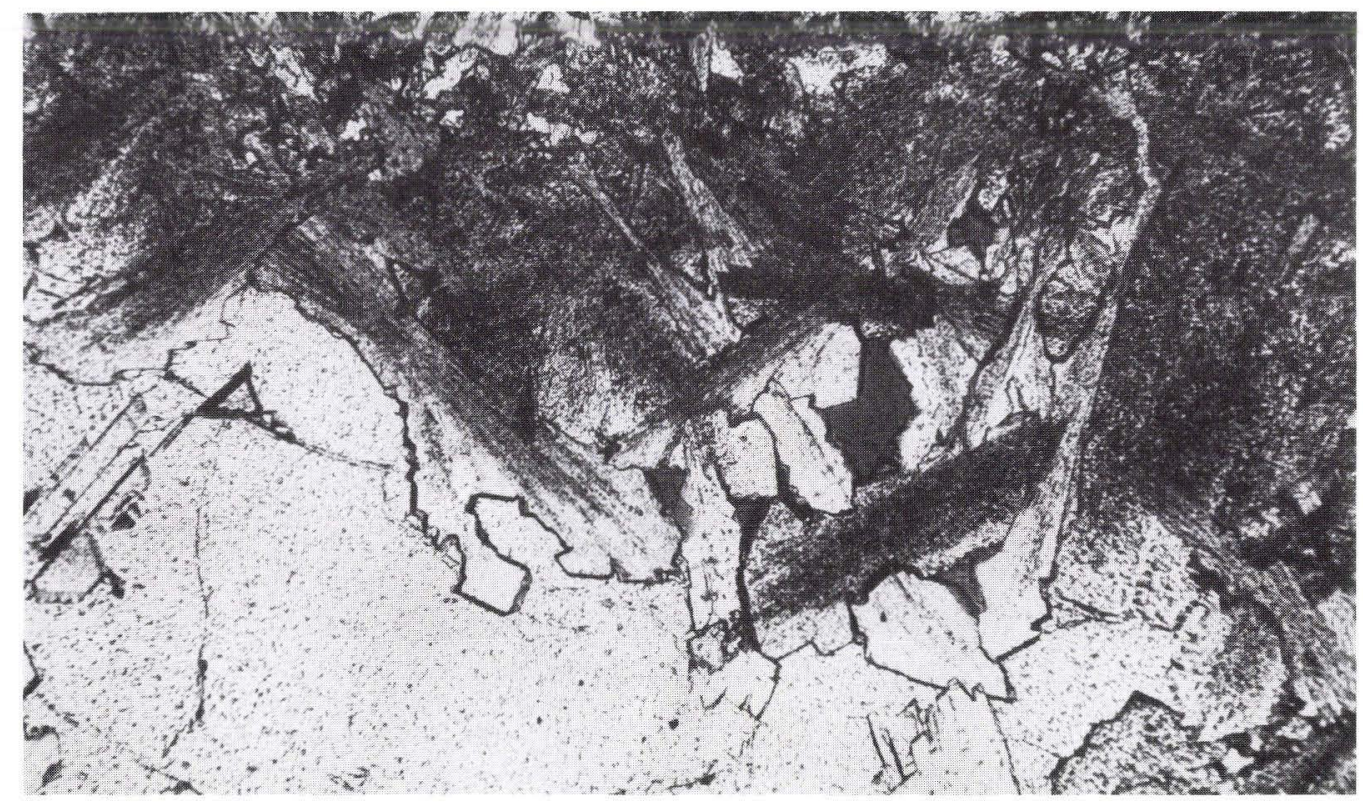

Fig. 12: Dolomite cement crystals (subunit I) around a celestine nodule (lowermost in the picture). The fan shaped structures are probably pseudomorphs after original gypsum aggregates. Note how the overgrown dolomite has well developed crystal faces where there has been no competition from neighbouring crystals. Note also how the thin strings of organic material render the crystals a radiate, sheaf like appearance. Such strings are often present inside the needle crystals.

Width of view $2.2 \mathrm{~mm}$ (sample 1828, depth: $2454.1 \mathrm{~m}$ ).

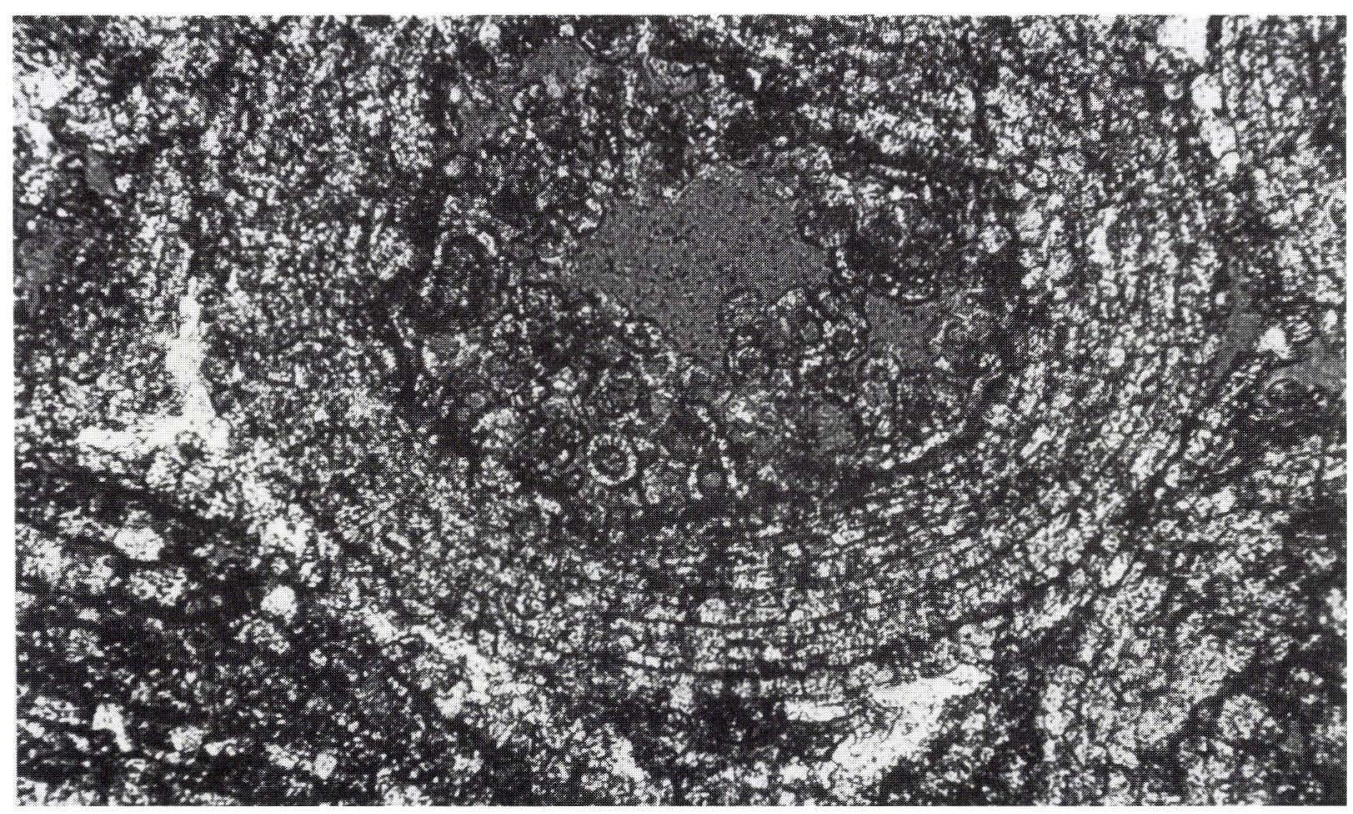

Fig. 13: Intra-ooidal, Fxn dolomite cement (subunit II). The sub to euhedral crystals are slightly larger than the crystals in the ooid. Note the intracrystalline pores. The intra-ooidal cement crystals are relatively richer in inclusions than the inter-ooidal cement crystals (e.g. fig. 14), and they never form »stubby «, isopachous rinds.

Width of view is $0.9 \mathrm{~mm}$. (sample 1768, depth: $2436.9 \mathrm{~m}$ ). 


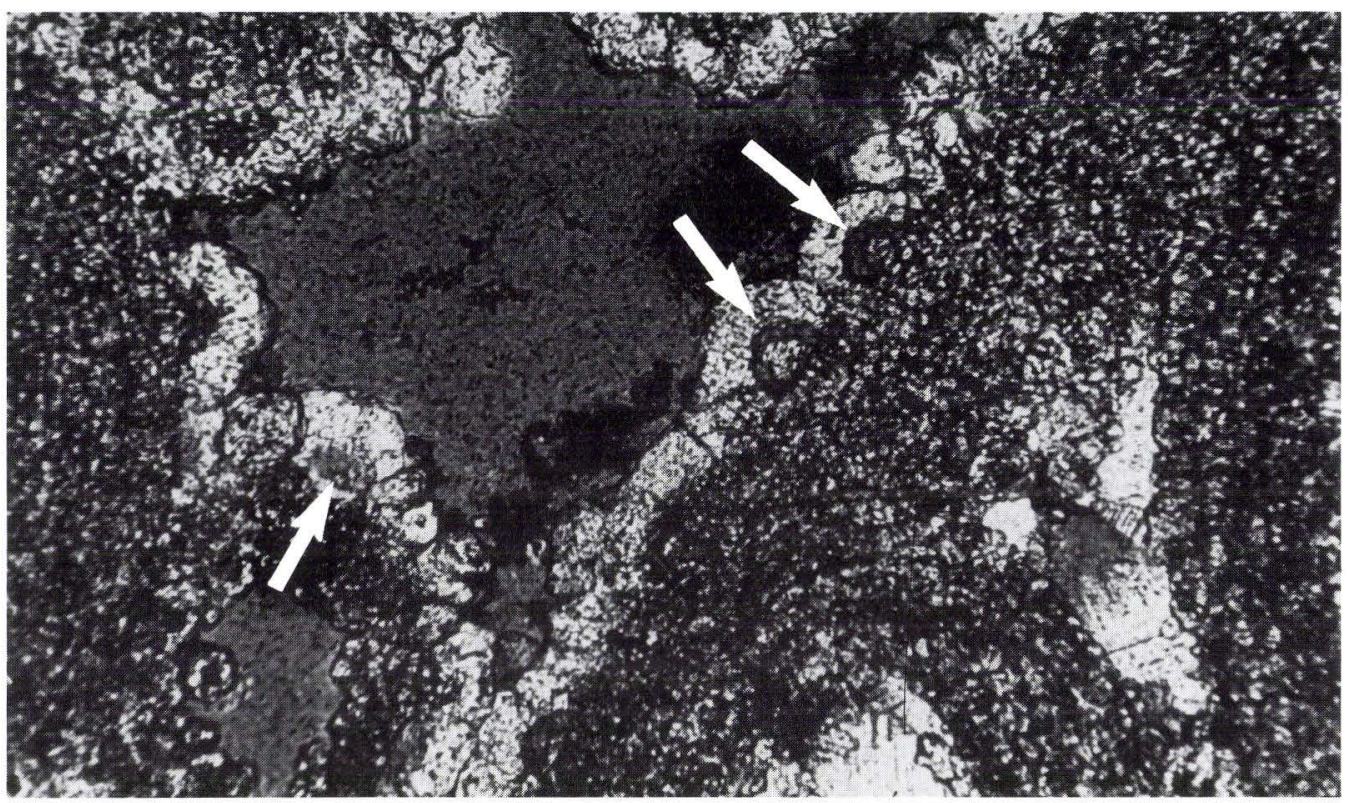

Fig. 14: Inter-ooidal dolomite cement forming isopachous rinds. Note the intracrystalline porosity in some of the crystals (arrows). A "growth-layer " has probably been dissolved.

Widths of view is $0.9 \mathrm{~mm}$ (sample 1761, depth: $2439.4 \mathrm{~m}$ ).

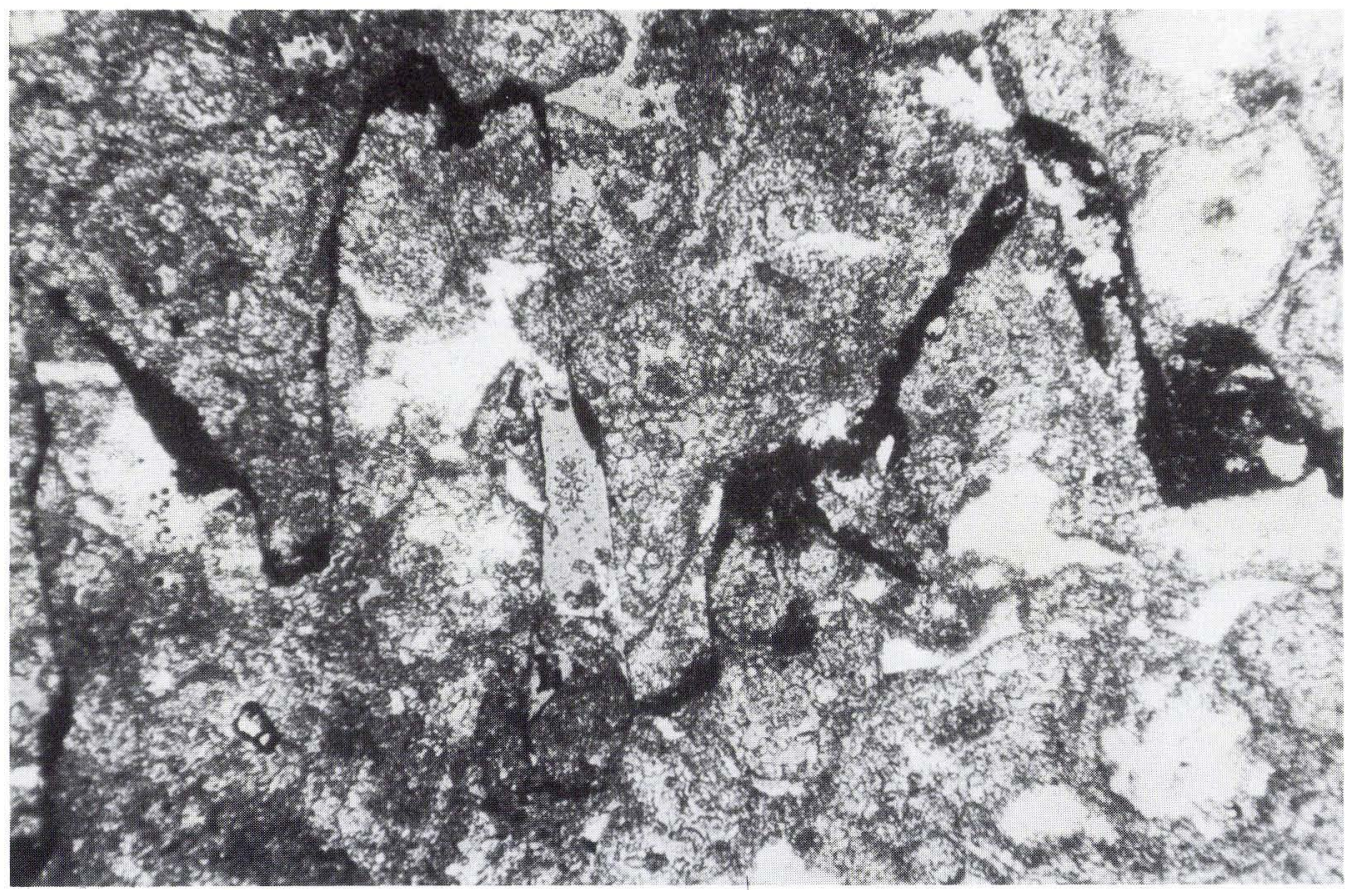

Fig. 15: A typical zig-zagging stylolite, draped with dark organic material. The rock around the stylolite is remarkably porous. As no stylolite can be formed along the walls of a cavity, a phase of leaching must have taken place after the stylolitization.

Width of view is ca. $2.2 \mathrm{~mm}$ (sample 1801, depth: $2424.0 \mathrm{~m}$ ). 
pore fluids late in the diagenetical history. The leaching which occurred after the stylolitization has often attacked the seams severely (fig. 11 and 15).

In summary, both the complexity of the pore geometry and the great variations of the porosity/permeability values of the present $\mathrm{Ca}-2$ rocks are primarily due to a varying amount of anhydrite cement. The relatively simple pore geometry with intra- and interooidal/-oncoidal pores, roughly corresponding to a Fxn, xenotopic, sieve mosaic fabric, has indeed been modified because of a varying degree of leaching and dolomite cementation, but the largest reservoir modifying agent is without doubt the anhydrite.

\section{On the diagenetic history}

All observed mineral phases or events of any importance for the reservoir quality were evaluated for relative timing of their genesis. The following diagenetic processes or events have been observed:

1. Early lithification and obviously also dolomitization.

2. Dolomite recrystallization by aggrading neomorphism.
3. First phase of leaching with formation of the inter and intra-oncoidal/ooidal pores, and the moulds of gastropods.

4a. Phase of stylolitization with associated

4b. fracturing.

5a. Precipitation of intra-oncoidal/ooidal dolomite cement.

5b. Precipitation of inter-oncoidal/ooidal dolomite cement forming equant rims.

6. Second phase of leaching causing a widening of fractures and an intracrystalline porosity of the dolomite cement.

7. Cementation by some ca. $100 \mu \mathrm{m}$ long needles and ca. $600 \mu \mathrm{m}$ long laths of gypsum (?).

8. Formation of dolomite pseudomorphs after those gypsum (?) crystals.

9. Precipitation of intercrystalline dolomite-cement (Mxn), especially around the needle crystals.

10. Cementation/replacement by anhydrite.

11. Cementation/replacement by Celestine.

12. Cementation/replacement by quartz.

13. Cementation by salt, probably halite.

14. Precipitation of dolomite (?) rhombohedrals, an extremely sparse porphyroid neomorphism.

15a. Third phase of leaching with the formation of mouldic porosity of the dolomite needle crystals.

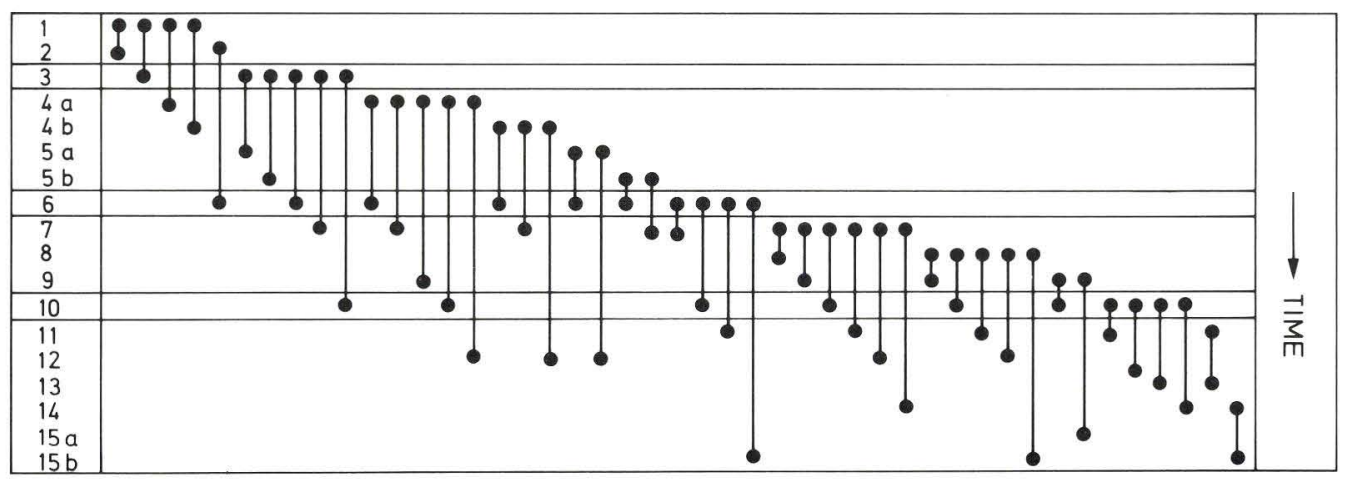

$\Phi=$ Verified relation of relative timing.

Fig. 16: The relative time relation between any set of two datable events observed in thin sections within the whole Ca-2 unit. The numbers refer to the diagenetic steps mentioned in the text. (Compare fig. 17). 


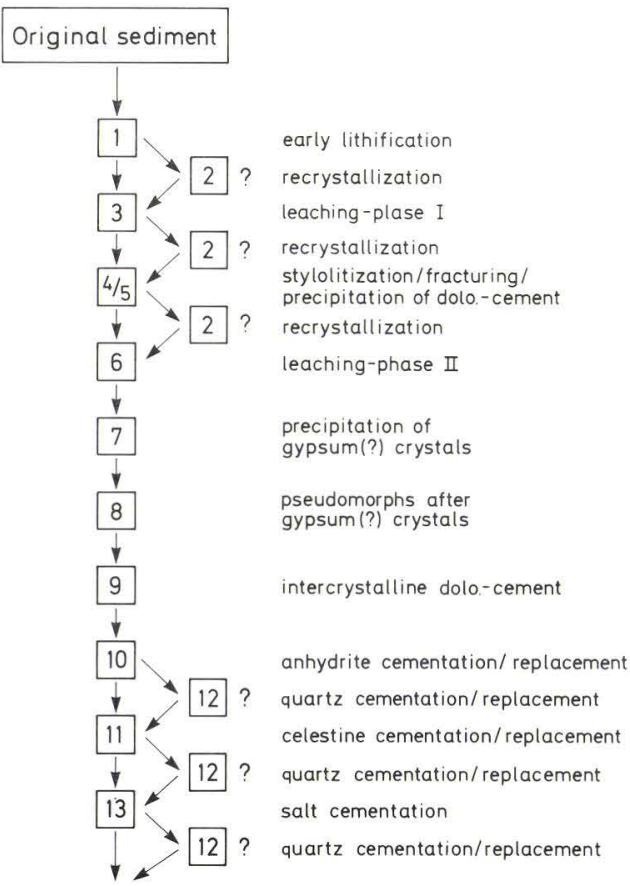

Present rock

Fig. 17: Flow-chart for diagenetic evolution.

15b. Dissolution of the dolomite (?)-rhombohedrals in connection with the formation of mouldic porosity.

A total of 43 time relations were observed in the thin section between pairs of those events. They are grouped together in fig. 16. This figure also shows that a few of the observed events could not be arranged in time: Thus the relative timing of the recrystallization (step no. 2), which resulted in the present dolomite fabric, is uncertain both in relation to the first leaching (step no. 3) and the stylolitization (step no. 4). However, the recrystallization probably occurred before the second phase of leaching (step no. 6).

Concerning the time for the precipitation of the quartz (step no. 12) some uncertainty is also present. It was precipitated after the anhydrite was introduced (step no. 10), but the time relation to the precipitation of ce- lestine and salt (steps no. 11 and 13) could not be established.

The same discussion applies for the latest phase of leaching (step no. 15).

Finally it has not been possible to ascertain the exact relative timing of the stylolitization/fracturing (step no. 4) in relation to either the first leaching (step no. 3) or the precipitation of dolomite cement (step no. 5). It has only been established that it took place before the second phase of leaching (step no. 6). However, it is likely that the carbonate that dissolved during the stylolitization formed the rim cement (step no. $5 b)$. If so, the stylolitization has occurred after the first phase of leaching as the precipitation of dolomite rim cememt is observed to have taken place after that phase of leaching. Accordingly the events can now be arranged in relative time in a more simple flow diagram, fig. 17. The two least important steps (14 and 15) have been ommitted. In the following an outline of the diagenetic "evolution" will be treated step by step in accordance with this diagram.

\section{Step 1: Early lithification/dolomitization}

Both the oncoidal and the oolitic deposits were evidently lithified relatively early: The closely packed oncoids have not been deformed by load compaction. On the other hand fracturing, and collapse of previously lithified oncoid carbonate is not found either. Such a fracturing and collapse of ooids is seen locally in subunit II. Also the preservation of the many delicate moulds from gastropods in subunit III (fig. 18), and a few well preserved Glomospira-like foraminifera in subunit II suggest an early lithification, as the carbonate mud inside the shells and the surrounding mud must have been stabilized before the skeletal parts of the animals were leached away.

The dolomitization of the original aragonite and/or magnesium calcite sediment has perhaps taken place in connection with the early lithification. Alternatively the dolo- 


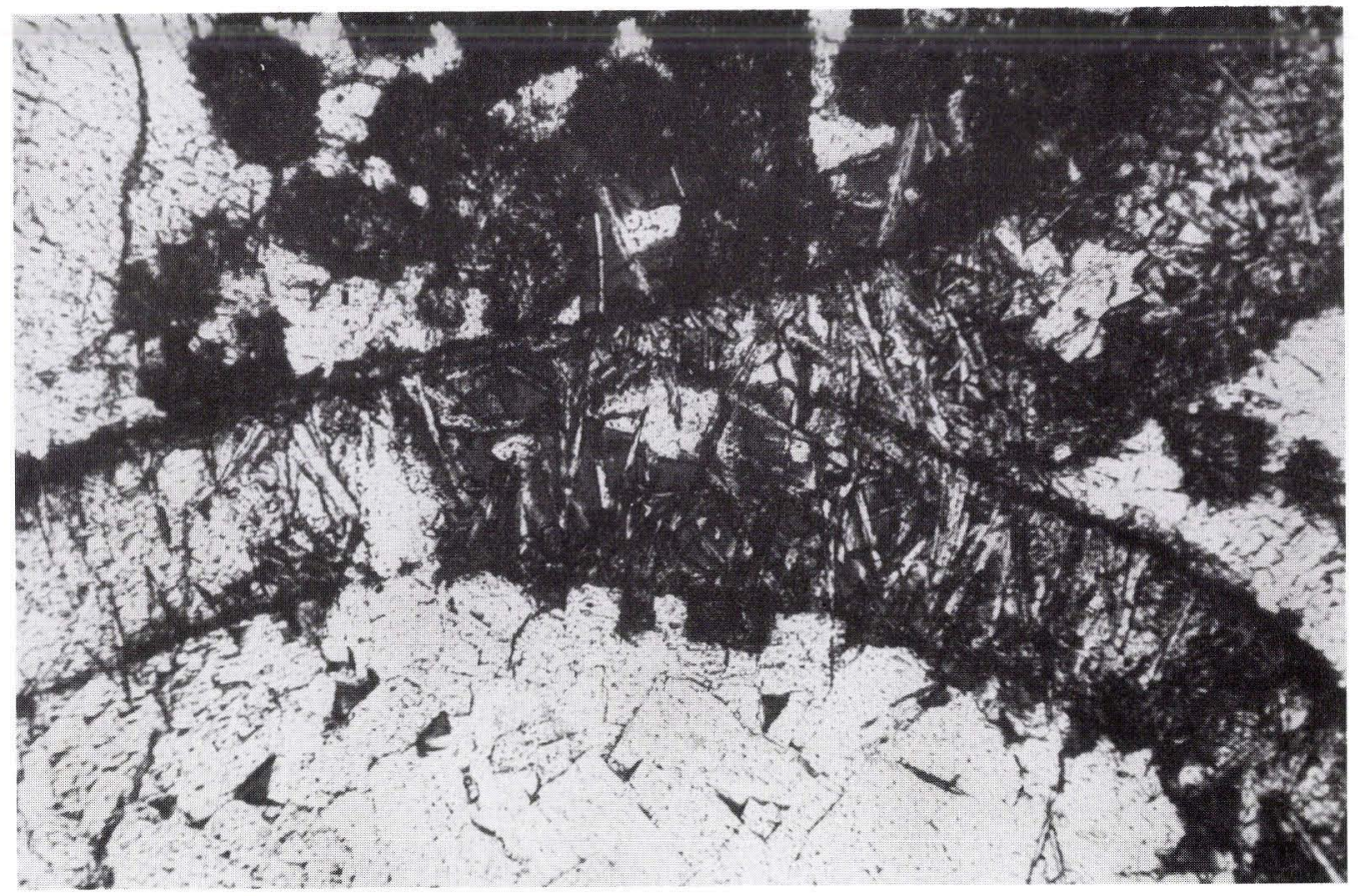

Fig. 18: Gastropod preserved as a mould. Only micritic (Axn) membranes are left. After a phase of leaching, needle cement was precipitated both from the walls, growing out in the mould itself, and outside in small cavities. Anhydrite (the light blocky minerals) was precipitated still later. A crystal crosses the wall of the mould.

Width of view is $2.2 \mathrm{~mm}$ (sample 1799, depth: $2425.3 \mathrm{~m}$ ).

mitization took place when the sediment was deeply burried as dolomitizing solutions may have been expelled from the basinal shale (the so-called Burial Compaction Model, see e.g. Morrow, 1982). The fact that some well preserved dolomitic ooids/ oncoids have not been subjected to an aggrading neomorphism speaks in favour of an early dolomitization.

\section{Step 2: Recrystallization}

The recrystallization - an aggrading neomorphism - has partly altered the original finely laminated structure of the coated grains. As stated above in the chapter on the rock fabric the preserved portions of the grains consist now mostly of fine (Fxn), anhedral, interlocking dolomite crystals. How- ever, in spite of that, the original concentric structures are often discernible (fig. 13), especially in the ooids in subunit I and II. The concentric laminae have often been intersected by carbonate crystals during the recrystallization. The original growth lines of the ooids appear, so to speak, as ghosts within the crystals.

In the lowermost part of subunit II the recrystallization has affected the ooids to a lesser degree (fig. 6). These ooids have a porphyrotopic texture. An incipient porphyroid neomorphism (Folk 1965) has probably taken place.

\section{Step 3: Leaching-phase I}

After a lithification the rock was subjected to a radical leaching, which probably took 


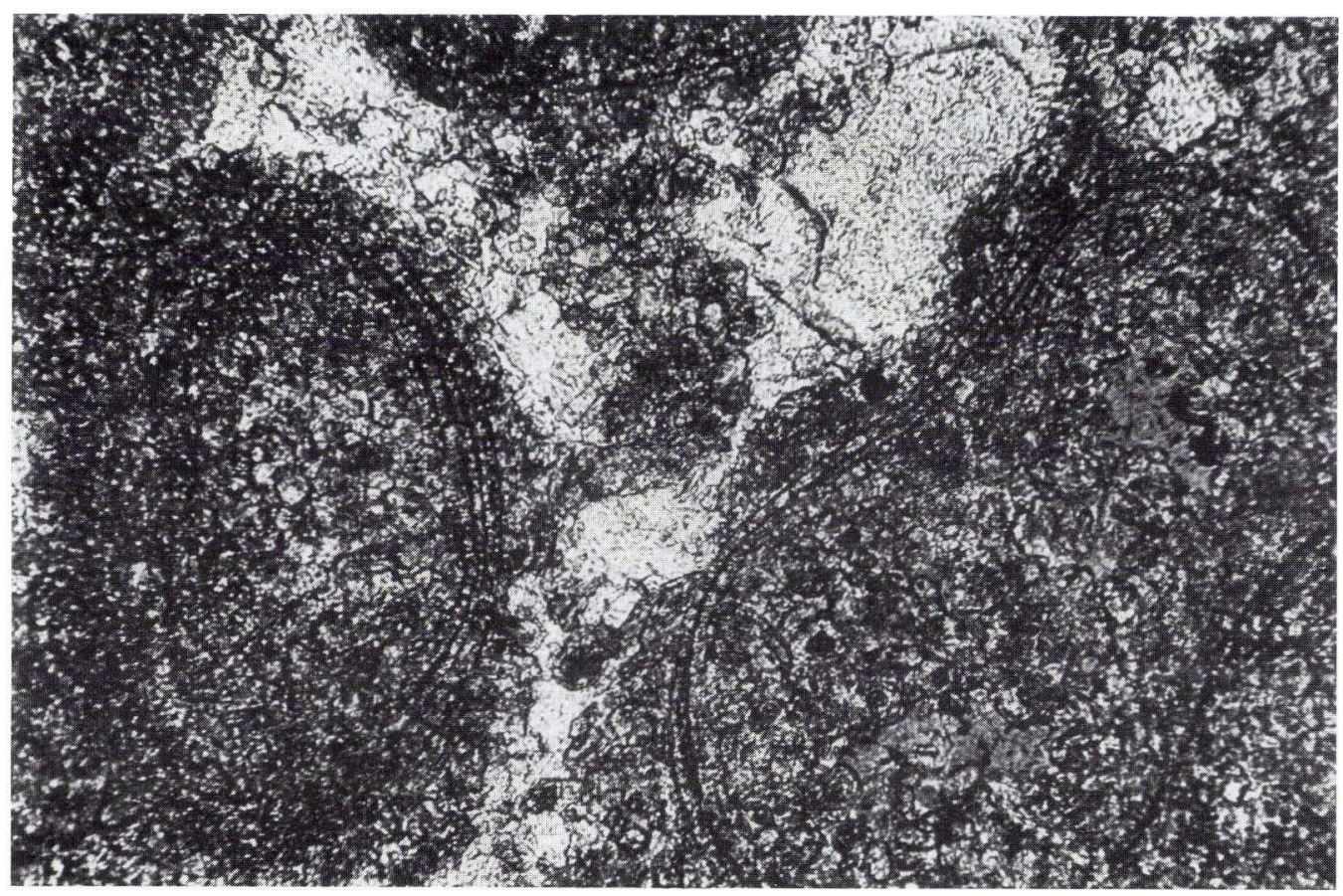

Fig. 19: Two cement filled ooids from subunit II. Several narrow, concentric pores are present inside the ooids; they look like growth-lines.

Width of view is $0.9 \mathrm{~mm}$ (sample 1774, depth: $2433.2 \mathrm{~m}$ ).

place relatively early in the diagenetic history. Numerous intraoncoidal pores were formed (fig. 6 and 13). The moulds after the gastropods and foraminifera shells were probably formed during the same phase of leaching.

Some peculiar, narrow and concentric cortex pores are often present in the ooids of subunit II, fig. 19. One or more growth layers in the ooids have been leached. It is not certain whether the cortex pores were formed during leaching-phase I or II (step 3 or 6).

\section{Step 4: Stylolitization}

The distribution of the stylolites discovered in thin sections is roughly in agreement with that of the macroscopic description (fig. 3). They were observed in ca. 1/3 of the samples of subunit $I$, in ca. $1 / 10$ of the samples of subunit II (in upper half), and in ca. 1/2 of the samples of subunit III.

The stylolites are mostly rather obliterated by dissolution of the surrounding carbonate (step 6), intersection by dolomite needles and anhydrite laths (step 7/8 and $10)$, or by precipitation of authigenic silica and sulphides (fig. 11 and 15). At the present stage of alteration the seams themselves consist often of a thin string of oillike organic material (fig. 20). The short fractures connected to the stylolites are enlarged by leaching (step 6), and sometimes afterwards have been cemented by anhydrite (fig. 20).

\section{Step 5: Precipitation of dolomite cement}

Dolomite cement was probably precipitated both inside and around the coated grains at the same time. The interooidal/oncoidal ce- 
ment is practically only forming an equant rim. The single crystals are fine to medium grained (Fxn-Mxn) with a stubby shape (fig. 14). The intra ooidal/oncoidal cement consists mostly of $30-40 \mu \mathrm{m}$ large (Fxn) sub/ euhedrals, which are most often smaller than the crystals of the coexisting inter ooidal/oncoidal rim-cement. It is very seldom present as isopachous rinds on the walls of he pores. Only relatively few hollow ooids/ oncoids are completely filled in by the cement (fig. 13 and 19).

The dolomite cement is often partly replaced by anhydrite and/or attacked by leaching. However, around many of the well preserved coated grains only very little cement is present at all (fig. 6). Perhaps a relatively high content of organic material in these grains has had a restrictive influence on the formation of the cement.

The subhedral/euhedral dolomite crystals in the lowermost part of subunit I (that is the rocks with "sucrosic" texture mentioned above) resemble very much the intra ooidal/ oncoidal cement crystals (fig. 13). In the central part they either contain a pore or an inclusion of organic (?) matter.

\section{Step 6: Leaching-phase II}

The pores formed during the early phase of leaching were enlarged by a renewed leaching, and thus the dolomite rim cement became in some instances undercut. Locally an intracrystalline porosity consisting of tiny median pores was developed (fig. 13 and 14). The intracrystalline porosity is most widespread in subunit II (fig. 9). For some unknown reasons the innermost and oldest part of the crystals has been dissolved.

The carbonate which surrounds the many

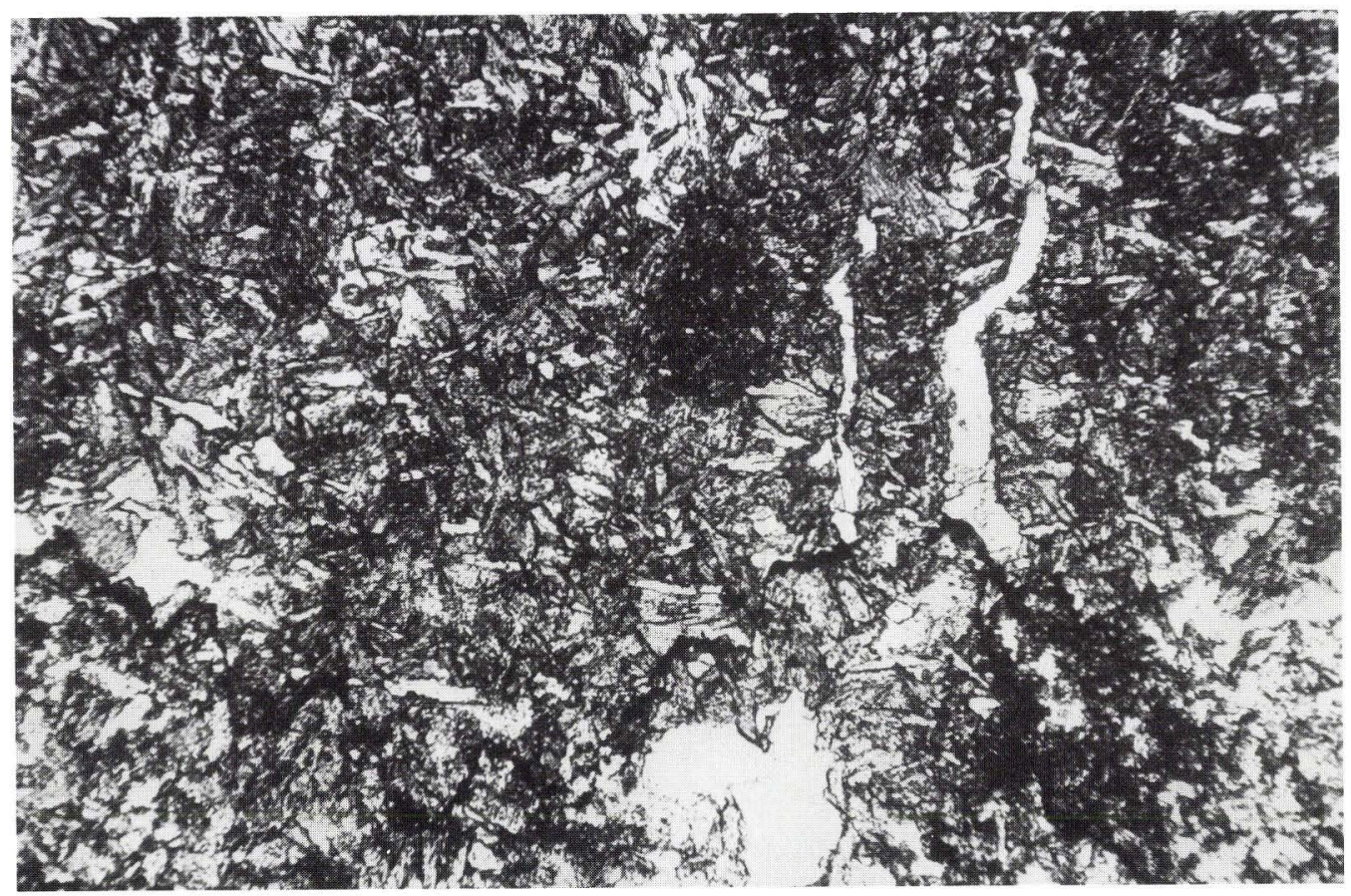

Fig. 20: A partly obliterated stylolite from subunit I, marked by a zig-zag string of hydrocarbon residue. The small fractures, at right angles to the stylolite plane, are filled in with anhydrite. The "needle matrix around the seam is finely porous. Numerous tiny intercrystalline pores are present even immediately along the seam.

Width of view is $2.2 \mathrm{~mm}$. (1/2 crossed nicols). (sample 1825, depth $2455.6 \mathrm{~m}$ ). 

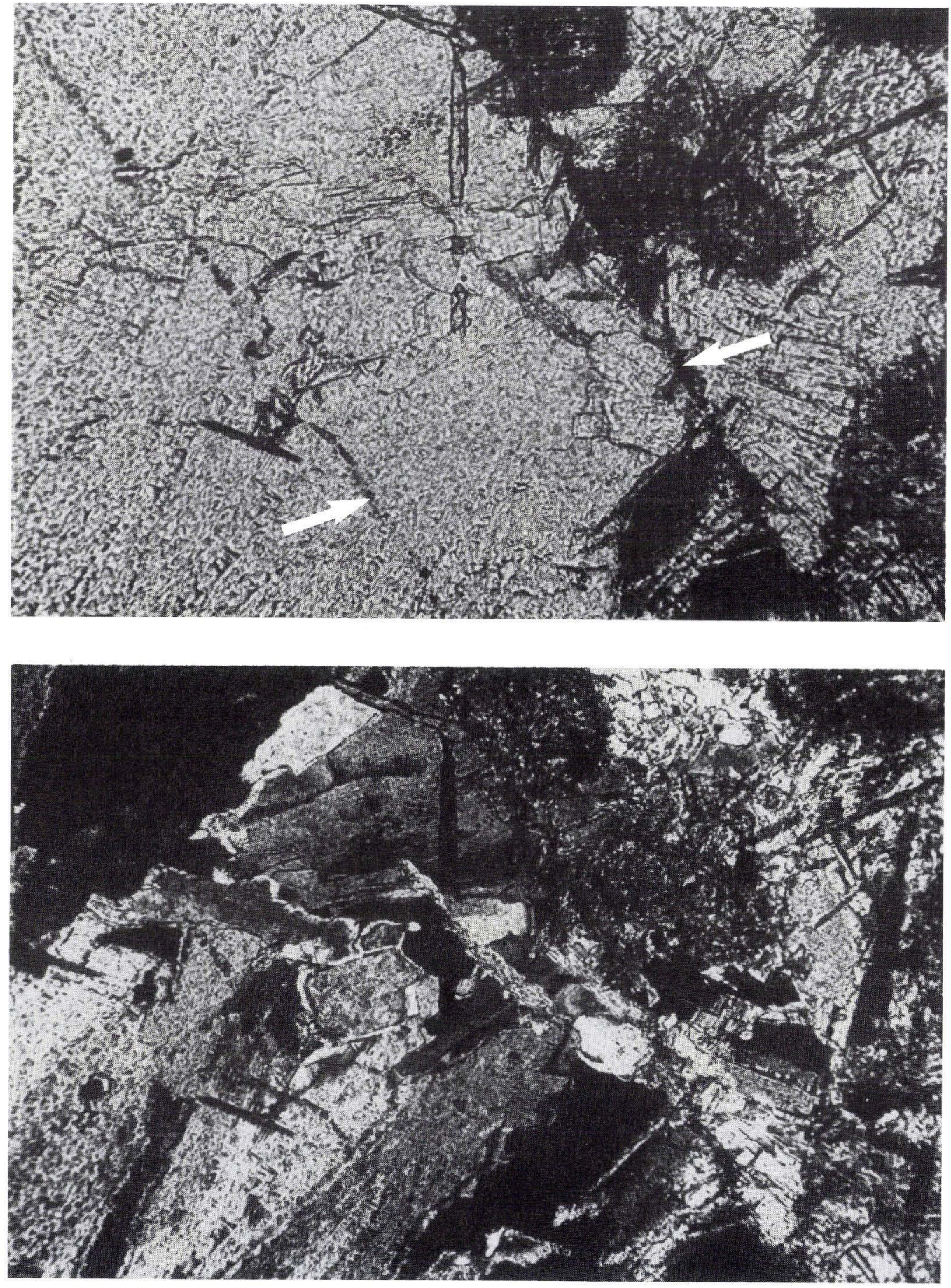

Fig. 21: A and B: Mould from a gastropod obliterated by anhydrite (compare fig. 18). Remains of the mould walls are still visible (arrows). Both the dolomite needles, precipitated in the mould, and the walls themselves, have obviously been attacked by the anhydrite. Figure B seen with crossed nicols. Width of view is $0.9 \mathrm{~mm}$. (Sample 1799, depth: $2425.3 \mathrm{~m}$ ). 
moulds of gastropods in subunit III is very affected by this leaching (fig. 18 and 21). Later anhydrite (step 10) has obviously partly replaced the carbonate. Also the carbonate around the stylolites was attacked as small cavities were formed in direct connection to the stylolites (fig. 15). Simultaneously the short fractures related to the stylolites were widened.

This second phase of leaching probably took place under phreatic conditions. A uplift of the rock to the vadose zone from a depth where stylolites could be formed (step 4) can hardly have taken place (cf. the subsidence curve of fig. 29).

\section{Step 7/8: Precipitation and subsequent pseudomorphic alteration of gypsum (?) crystals}

A cement of needle-like crystals, which now consists of dolomite has been precipitated in the pore spaces previously formed during the two phases of leaching. It is very common in the subunits I and III, but absent in subunit II (fig. 9).

The needle crystals are mostly slender and 80 to $130 \mu \mathrm{m}$ in length. They often contain some organic (?) inclusions which form a central string parallel to the optical c-axis (fig. 12). Although the needles now consist of dolomite, they are morphologically like gypsum crystals, and they often form rosettes and crosses. They sometimes show a sweeping extinction with crossed nicols.

The single needle-like crystals usually grow as a rim cement from the preserved remains of oncoids and gastropod moulds (figs. 11, 18 and 21). They are randomly orientated whereby they often create an open network (fig. 18). The needles are locally so closely packed that the rock almost has a felty texture (fig. 12). Needles have also been observed inside tiny undercutting

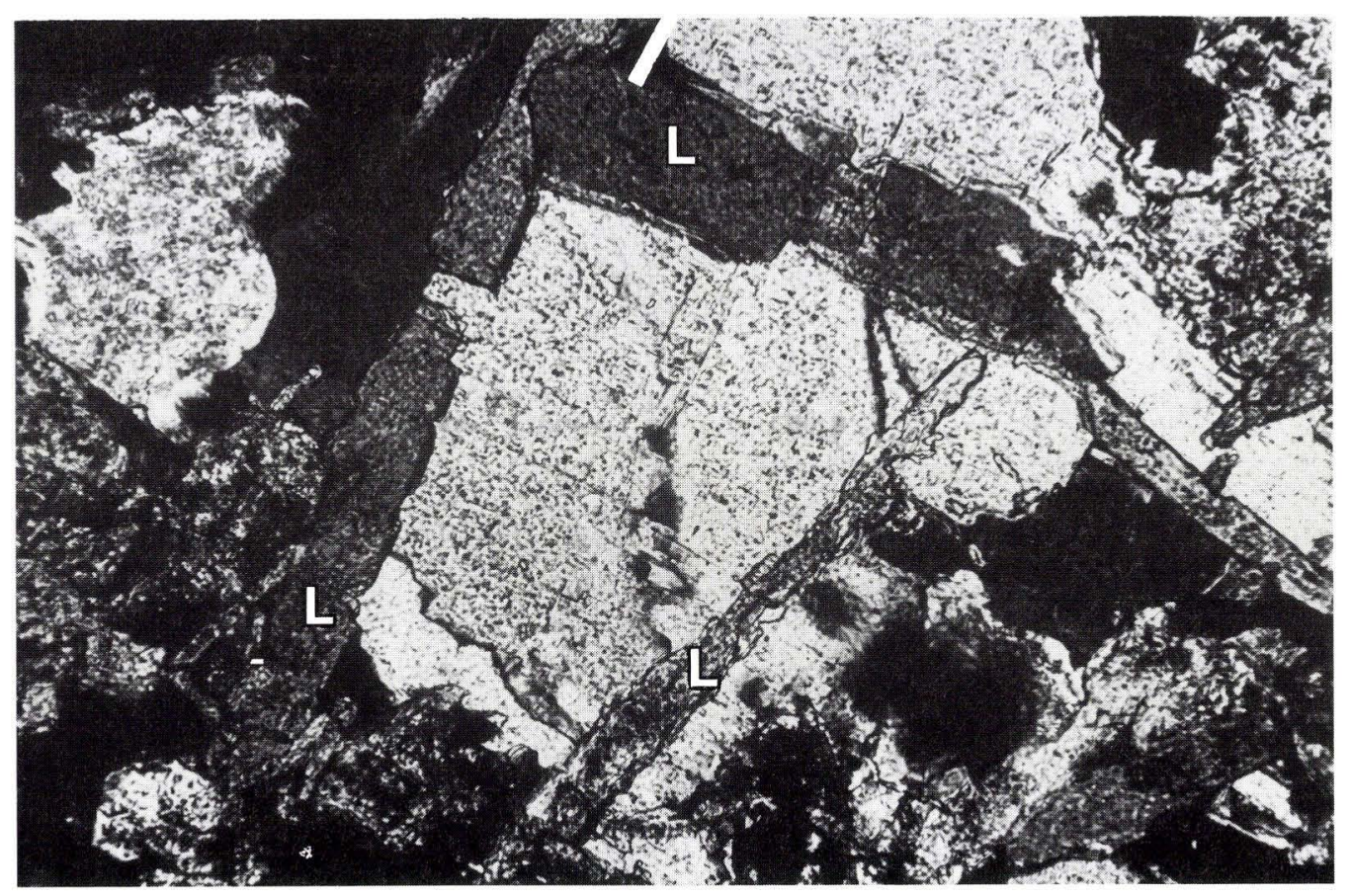

Fig. 22: Dolomite laths (»L«) partly replaced by anhydrite.

Width of view is $0.9 \mathrm{~mm}$. Crossed nicols. (sample 1785, depth: $2428.8 \mathrm{~m}$ ). 


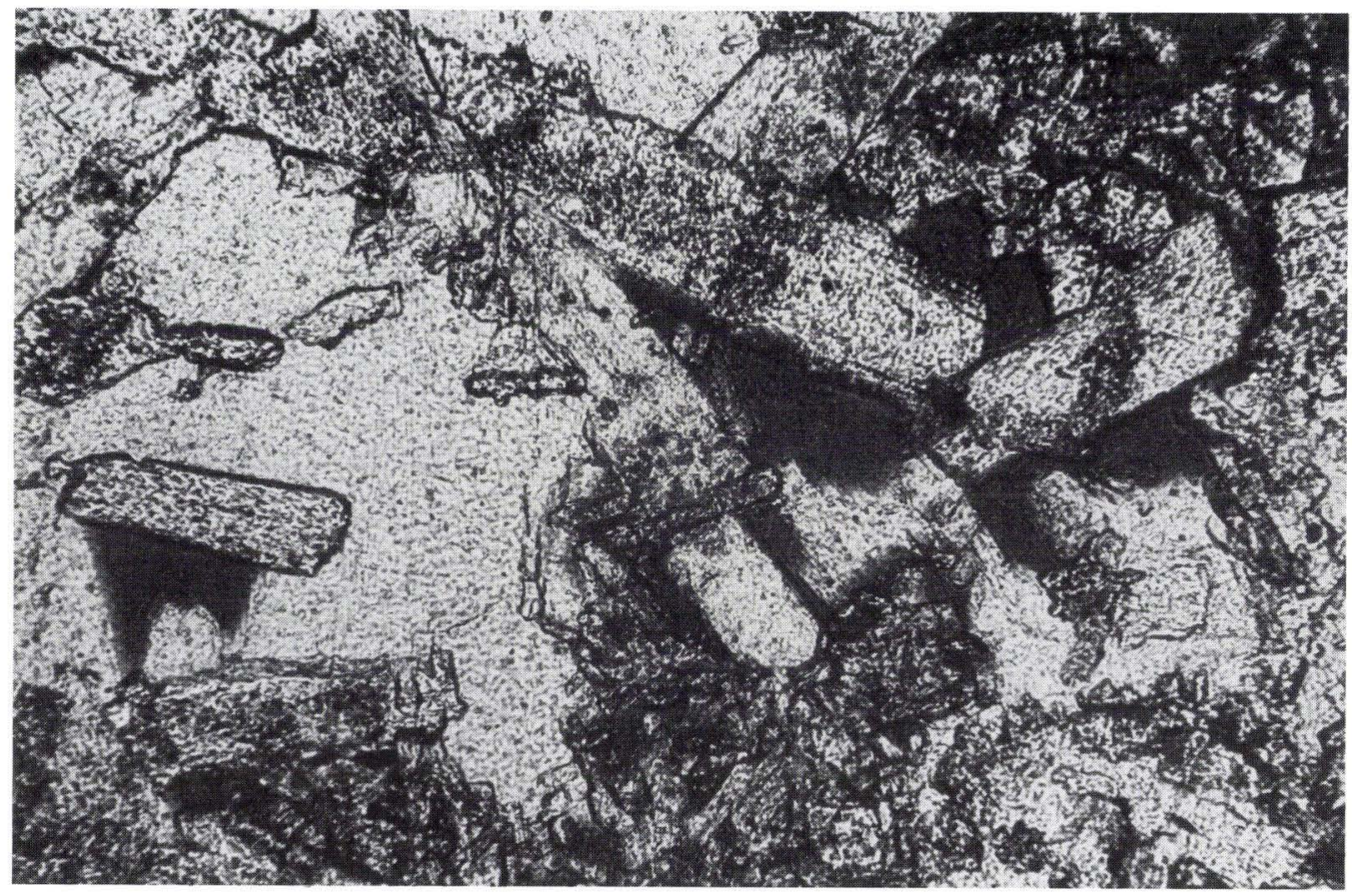

Fig. 23: Dolomite laths which are enclosing Axn-VFxn carbonate material. One of the laths has partly enclosed one of the needle-shaped crystals as well.

Width of view is $0.9 \mathrm{~mm}$ (sample 1785, depth: $2428.8 \mathrm{~m}$ ).

pore spaces behind the dolomite rim cement (step 6.) and in small cavities around the stylolites (fig. 11).

In one sample in subunit III (at $2428.8 \mathrm{~m}$ ) and in several of the samples in subunit I some $60-100 \mu \mathrm{m}$ wide and $400-800 \mu \mathrm{m}$ long laths coexist with the needles. The laths consist of dolomite. They often form rosettes and crosses like the needles, and sometimes they have a sweeping extinction with crossed nicols. Perfect crystal faces of the laths are sparse, rather they are etched or sometimes ruined by the anhydrite (step 10, fig. 22). During their growth they have often surrounded and isolated bits of carbonate thereby creating a poikilotopic texture (fig. 23). Sometimes they have also partly engulfed some of the smaller needles (fig. 23). Some individual dolomite laths have an angular termination. A number of angles between these crystal faces were measured. No perfect longitudinal and cross sections are available. Generally, however, the angles correspond rather well to those of gypsum (Tröger, 1971 and von Phillipsborn, 1967).

In conclusion both the dolomite laths and the smaller dolomite needles are supposed to be pseudomorphs of gypsum. Both types of crystals probably represent only one generation of original gypsum-cement. This assumption seems to be confirmed by the fact that transitional sizes between needles and laths occur in several of the samples of subunit I, especially in the lower half.

\section{Step 9: The precipitation of intercrystalline dolomite cement}

After the precipitation of needle and lath cement a renewed cementation took place. This was the intercrystalline, fine or medium crystalline dolomite cement that sur- 
rounds some of the needle crystals. The cement only contains very few inclusions compared to all previously formed dolomite crystals. The cement is considered only to have affected the porosity/permeability of the rock slightly, owing to its very scattered occurrence. In some instances the cement has affected the needle crystals themselves so that only ghosts are left behind inside the cement crystals. Consequently, the surrounding cement has not always been quite passive: sometimes it has consumed the older needle crystals (a neomorphic alteration, cf. Folk, 1965, p. 21). It is likely that the conversion of the gypsum needles and laths into dolomite (step 8) took place simultaneously with the present phase of cementation (fig. 17). Generally there is optical continuity between the needles/laths and the new cement. The overgrown needles/ laths have crystal faces where they protrude into larger cavities (fig. 12).
In places a few of the overgrown needlecrystals have suffered leaching (step 15) with the formation of moulds. In some of the samples in the lower part of subunit I it is not the needle crystals which have been dissolved, but rather the dolomite at the contact between the needle and the surrounding cement (fig. 9 and fig. 24).

\section{Step 10: Anhydrite cementation/ replacement}

The precipitated anhydrite in places has highly affected the porosity/permeability of the rock as the pore spaces were nearly totally filled. The anhydrite is partly a passive cement (fig. 6), partly a replacement of carbonate (fig. 21). The replacive anhydrite sometimes forms augen up to $1 \mathrm{~cm}$ in cross section (compare fig. 3). Residuals of the dolomite are usually present inside the anhydrite crystals.

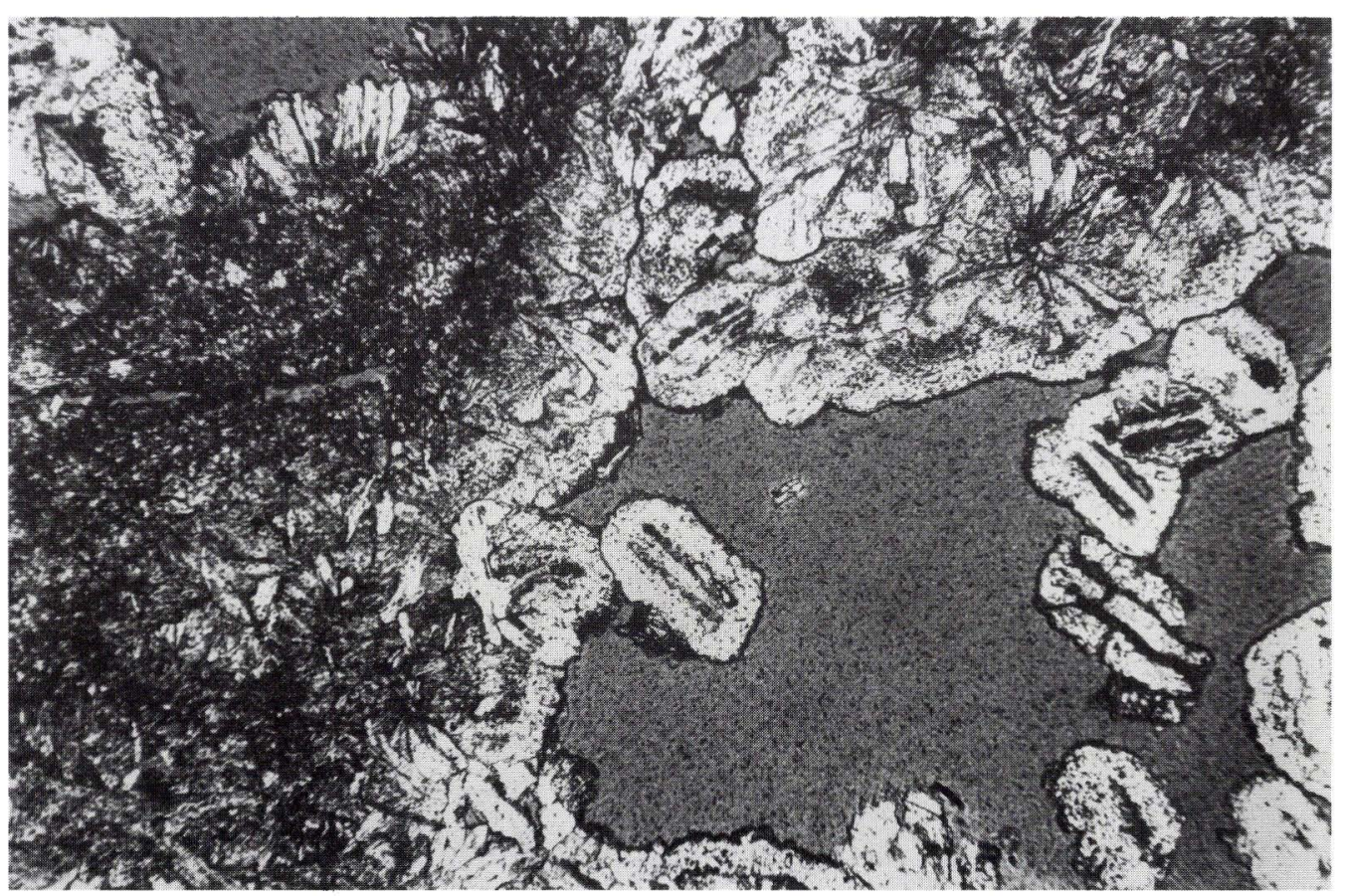

Fig. 24: Intra-crystalline porosity. The cylindrical pores (double pores as observed in thin section) have been formed along the boundary between the needles and the surrounding cement. Also the outer surface of the cement has been slightly etched.

Widths of view are $2.2 \mathrm{~mm}$ (sample 1811, depth: $2457.5 \mathrm{~m}$ ). 


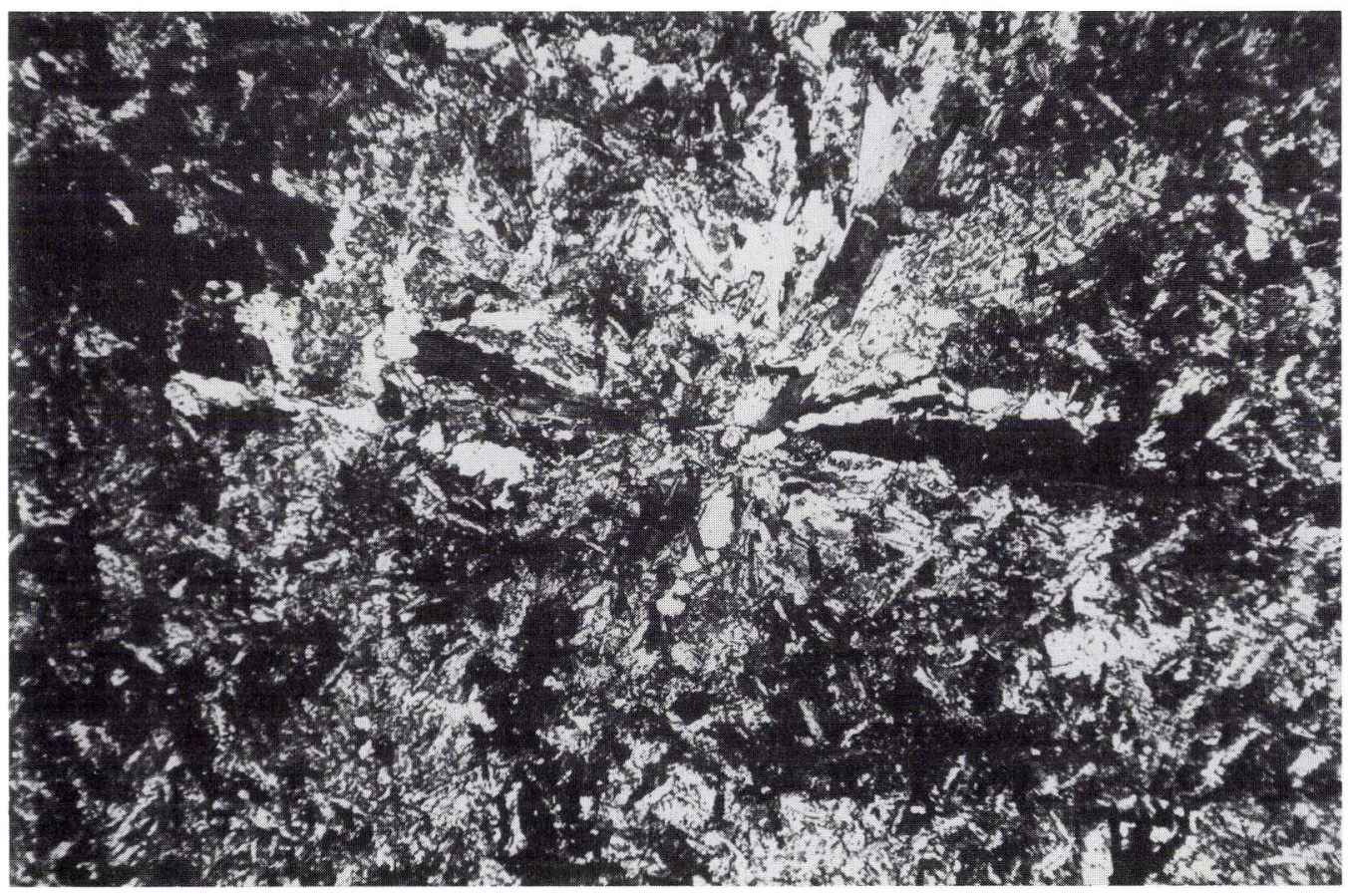

Fig. 25: Radiating anhydrite crystals, which have partly replaced, partly enclosed the dolomite crystals (poikilotopic fabric).

Width of view is $2.2 \mathrm{~mm}$ (sample 1781, depth: $2430.4 \mathrm{~m}$ )

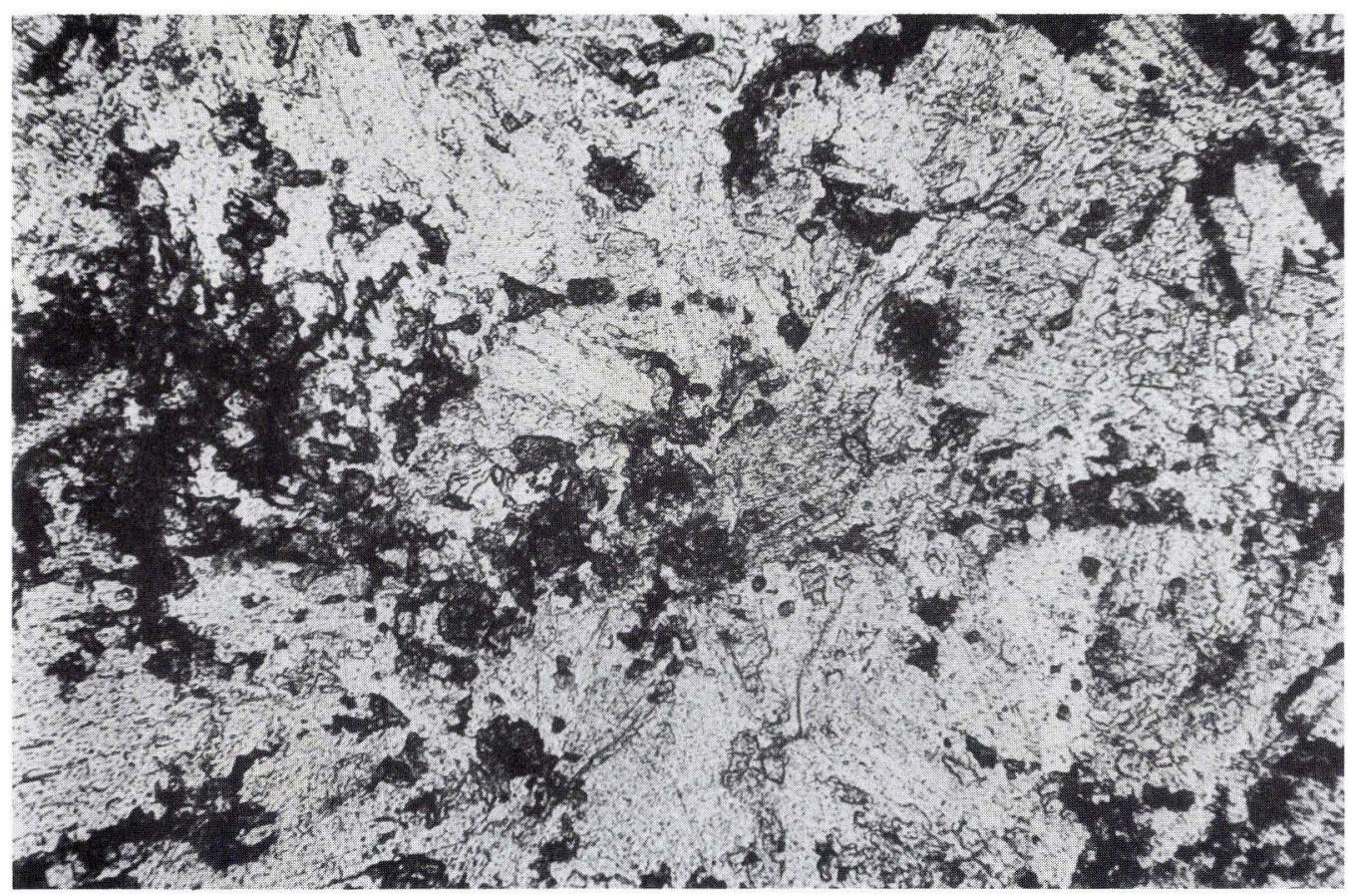

Fig. 26: A strongly anhydritized oolite. Only circles of dolomite disclose the presence of the original ooids. This sample represents a ca. $26 \mathrm{~mm}$ thick bed within which massive areas, like that on the figure, alternate with porous layers without anhydrite.

Width of view is $2.2 \mathrm{~mm}$. (Sample 1857, depth $2443.7 \mathrm{~m}$ ). 
Normally the anhydrite is coarsely crystalline. It consists of scattered individual crystals or groups of crystals. The latter have either a lath-shaped mosaic texture (fig. 21), or a felted to aligned-felted texture (Maiklem et al., 1969). In places with felted texture the anhydrite crystals are frequently arranged in spherulites (fig. 25). In a few samples of subunit II a relatively coarse grained blocky anhydrite has grown at the expense of these aggregates. In subunit I the rock is locally completely massive as the anhydrite has replaced most of the original dolomite, fig. 26 .

\section{Step 11: Celestine cementation/replacement}

The celestine $\left(\mathrm{SrSO}_{4}\right)$ constitutes few scattered coarsely, euhedral crystals throughout the whole unit $\mathrm{Ca}-2$. Celestine crystals are also found together with the anhydrite in the relatively large augen in subunit I (fig. 3 and fig. 12). The celestine has often partly replaced some of the anhydrite crystals during its growth. However, in two samples from subunit I, the reverse appears to have happened, but maybe the blocky anhydrite here represents a second generation of anhydrite - a recrystallized anhydrite?

\section{Step 12: Cementation/replacement by quartz}

Sub- to euhedral quartz crystals replacing anhydrite are found scattered in the whole $\mathrm{Ca}-2$ interval, but they are most abundant in subunit I (fig. 27). In subunit I the quartz grains are sometimes arranged in spherical shell-formed aggregates $1.5 \mathrm{~mm}$ across as if an oolitic structure has directed the growth.

Besides the anhydrite crystals, which have been more or less replaced, the quartz

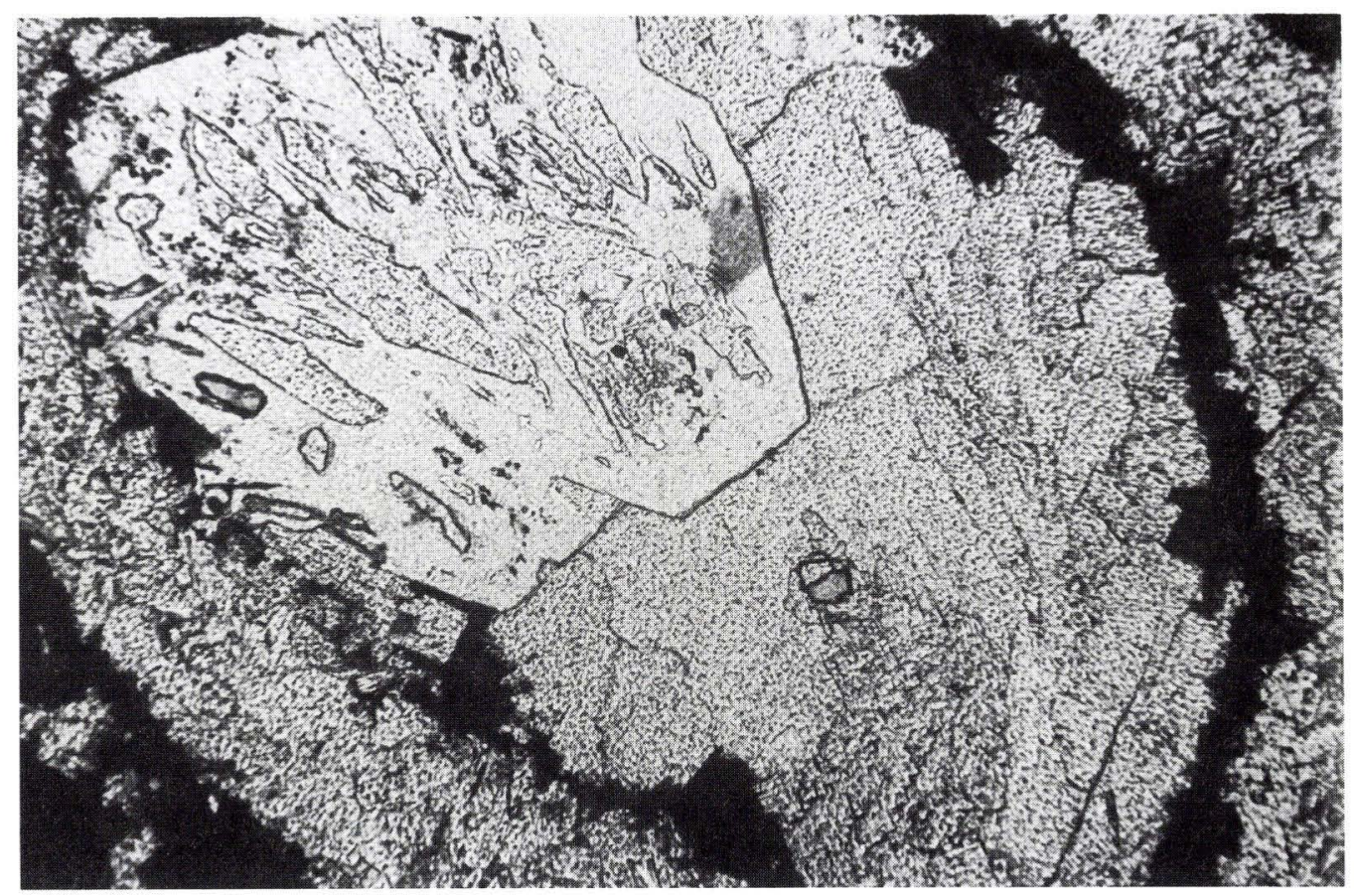

Fig. 27: A quartz crystal that has partly replaced the anhydrite (poikilotopic fabric). During its growth the quartz has also enclosed carbonate material (the tiny scattered spots around the residual anhydrite).

Width of view is $2.2 \mathrm{~mm}$. (Sample 1797, depth $2426.3 \mathrm{~m}$ ). 


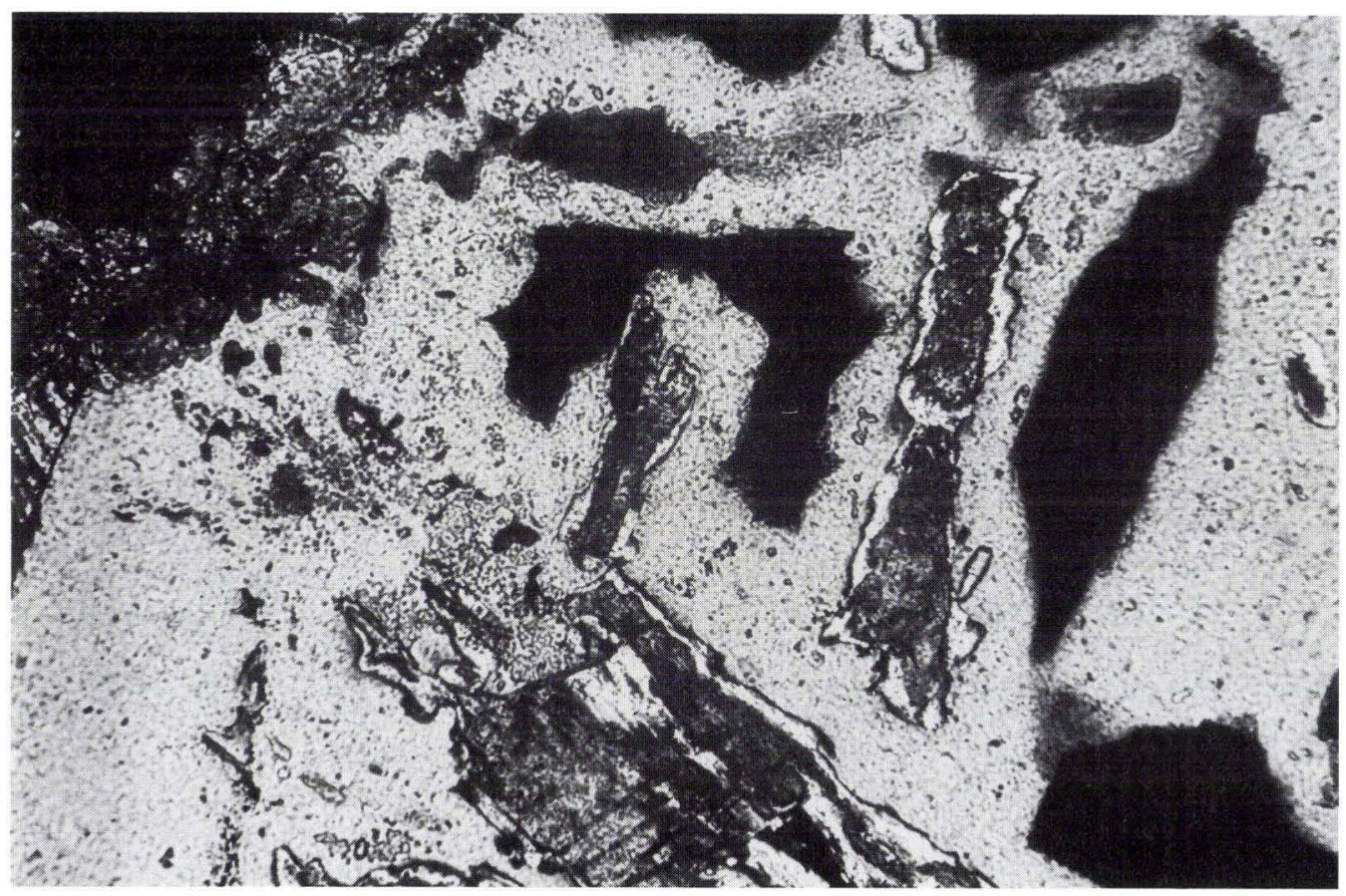

Fig. 28: A part of a subhedral quartz crystal, which has partly replaced anhydrite laths. The configuration of the pores seems to be defined by the original anhydrite laths.

Width of view is $0.9 \mathrm{~mm}$. Crossed nicols. (Sample 1792, depth: $2427.4 \mathrm{~m}$ ).

crystals have also enclosed carbonate material during their growth, but apparantly without having attacked it.

Pores are occasionally present inside the quartz crystals (fig. 28). These pores have angular boundaries. The resin used in the thin section preparation has not entered these pores. It is assumed that these pores were present before the replacement by quartz took place, and that the configuration of the internal pores was defined by the shape of the original anhydrite laths. The quartz replacement commenced at the faces of the anhydrite laths which were located around the pores, and during the proceeding growth of the quartz crystal replacement continued towards the central part of the laths.

\section{Step 13: Cementation/replacement by halite}

Mostly coarsely crystalline halite crystals are present scattered in the entire $\mathrm{Ca}-2$ unit. Locally they are more frequent and may affect the reservoir quality. The crystals have surrounded both anhydrite, celestine and carbonate needle crystals during their growth. The salt has partly replaced the anhydrite as residuals of anhydrite crystals often are present inside the salt crystals. Overgrowth of salt crystals seems to have had a preservational effect on the carbonate needle crystals: the needles are rather abundant and usually relatively well preserved inside the salt crystals. The salt crystals are rich in inclusions of liquid and organic matter which often are concentrated centrally. 
Step 14/15: Precipitation and dissolution of dolomite (?)-rhombs

A number of scattered rhombohedral moulds are present in several of the samples (fig. 9), mainly inside the oncoids. They are probably moulds of dissolved dolomite crystals, and they have replaced the dolomite matrix during their growth. The dolomite (?) crystals have also replaced anhydrite. In several places an intra-mouldic residue of anhydrite has been found, which is in optical continuity with the unattacked part of the anhydrite crystal outside the mould.

\section{The introduction of oil}

Oil is found in some of the pores in samples from the lower half of subunit II and in the entire subunit I (compare fig. 3). The oil was introduced after the phase of anhydritization.

The relationship between some of the diagenetic phases and the burial history

The burial history of the Løgumkloster-1 Zechstein carbonate is shown in figure 29. Four major epochs of burial are seen:

1) A relatively very rapid burial from the beginning of Zechstein (P2) to Middle/ Late Jurassic ( $\mathrm{J} 2 / \mathrm{J} 3)$.

2) A uplift and erosion in Late Jurassic time (J3).

3) Stable conditions with slow burial in Early Cretaceous (K2).

4) A rapid burial from the beginning of Late Cretaceous (K2) to present.

This burial history is comparable to that in the Aabenraa-1 well (fig. 1) (Stentoft \& Nygaard, 1985).

It is quite obvious to relate the most

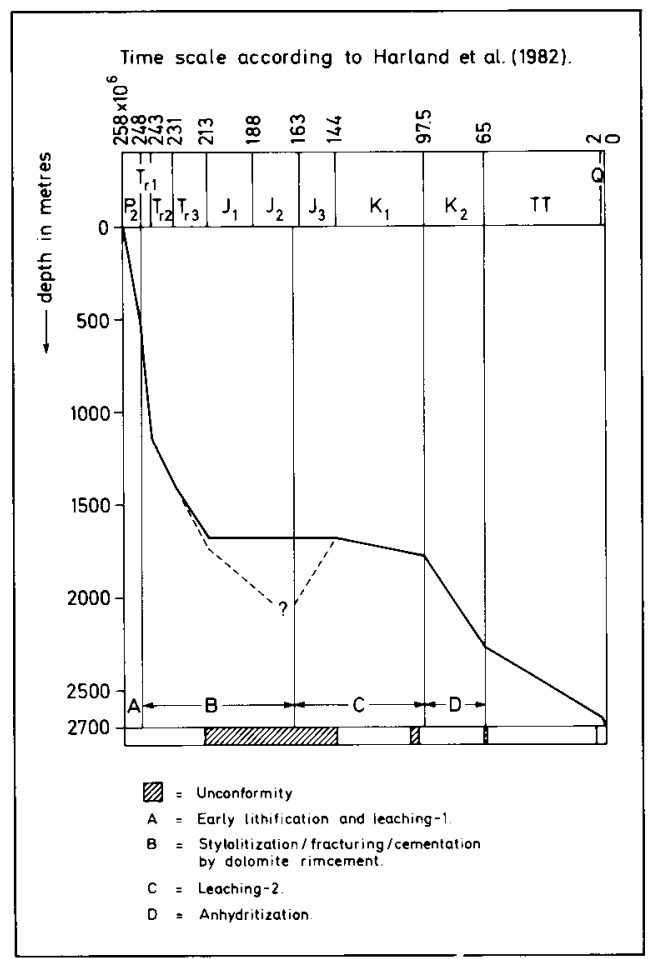

Fig. 29: The major postdepositional diagenetic phases $(A-D)$ tentatively related to depth of burial of the Zechstein carbonate versus geological time.

important diagenetic phases to each their burial epoch in following way: The phase of chemical compaction (step 4) to the rapid Triassic-Jurassic burial, when the $\mathrm{Ca}-2$ sediment was buried to an adequate depth of minimum, perhaps 500 metres. The phase of leaching-II (step 6) to the tectonic phase of uplift in the Late Jurassic, during which overpressured pore water was released and pore water having another $\mathrm{CO}_{2}$ partial pressure, may have been introduced (mixing corrosion, Bögli 1978). This phase may have continued into the Early Cretaceous. Finally the phase of anhydritization may be related to the renewed rapid burial in the Late Cretaceous. Compactional excess fluid from the underlying sulphate rock (the Werraanhydrite) could have been introduced during this period. 
A comparison between the diagenetic history of the Ca-2 rock of Løgumkloster-1 and that of the corresponding rock of Brøns-1

The Ca- 2 rock in the Brøns- 1 well situated ca. $20 \mathrm{~km}$ northwest of the Løgumkloster-1 well (fig. 1) has also been investigated petrographically (Stemmerik et al., 1986 and Stemmerik et al., 1987). The Ca-2 interval covers ca. $20 \mathrm{~m}$ (from ca. 2271 to ca. $2290 \mathrm{~m}$ b.RT).

The rock has been subjected to practically the same diagenetic history as the $\mathrm{Ca}-2$ rock of Løgumkloster-1. The most important diagenetic events, which also here have strongly affected the quality of the potential reservoir, are two phases of leaching, a chemical compaction followed by a precipitation of inter-oncoidal/ooidal dolomite cement, and an anhydritization.

The only conspicious diagenetic difference between the two Ca- 2 units are: 1) The presence of some scattered, ca. $50 \mu \mathrm{m}$ long slender fusiform dolomite crystals, probably pseudomorphs after gypsum, which are found inside the Axn dolomite of Brøns-1, that is first and foremost inside the wellpreserved oncoids/ooids. These replacing crystals are probably precipitated very early in the diagenetic history. 2) No intra-crystalline porosity was observed in $\mathrm{Ca}-2$ of Brøns-1. That is, the dolomite cement crystals have not been hollowed out by leaching.

Because of the close similarity of the diagenetic history between the two corresponding units of Løgumkloster-1 and Brøns-1 there is reason to expect that the diagenetic concepts mentioned above hold for larger areas of southern Jylland, especially as the underlying Ca-la rock of Varnæs- 1 and the upper half of the Ca-la rock of Aabenraa-1 practically have suffered the same diagenetic history (Stentoft \& Nygaard, 1985, and Stemmerik et al., 1986). 


\section{Discussion}

It was stated above that a total of 43 time relations were observed in thin sections between pairs of diagenetic events (fig. 16). However, the interpretation of these relations to form a diagenetic history was based on a few assumptions:

Firstly, a single process was assumed to have taken place simultaneously, or nearly simultaneously, in the entire $41 \mathrm{~m}$ thick $\mathrm{Ca}-2$ sequence. A single process was not considered to have taken place repeatedly in the course of time; if it had, it would have meant that a rock at one level of the $\mathrm{Ca}-2$ unit had gone through say steps one to ten of the diagenetic history (fig. 17) whereas the rock in another level at the same time had only gone through say steps one to six. In this way it would be meaningless to relate the diagenetic phases to the burial history of the Zechstein carbonate.

Secondly, it was taken for granted that the intra-ooidal/oncoidal dolomite cement precipitated at the same time as the interooidal/oncoidal dolomite rim cement (step 5). Maybe this assumption is wrong. Anyhow, there is always a distinct difference between the two cement types: The interooidal/oncoidal cement crystals are greater, and less rich in inclusions and intracrystalline pores than the coexisting intra-ooidal/ oncoidal cement crystals. The shape of the pores is also different. The outline of the pores inside the inter-ooidal/oncoidal cement crystals is most often angular as if a growth layer has been dissolved (fig. 14), whereas the pores of the intra-ooidal/oncoidal cement crystals are more irregular outlined, and always situated in the middle of the crystals (fig. 13). Perhaps the latter have been formed by leaching of an inclusion of an organic-rich matter, or maybe the crystals have been precipitated around some tiny peloids, which have now disappeared, before the oolitic structure was built up; i.e. an accumulation of peloids with accompanying cement has formed so to speak a nucleus around which the oolitic structure was generated. In any case, the intra-ooidal cement crystals never form a "stubby" rim cement like the inter-ooidal cement crystals.

Thirdly, it was claimed that the leaching which created the intracrystalline porosity in the dolomite cement crystals also attacked the finegrained dolomitic material behind the rim cement and widened the fractures (step 6 in fig. 17). That the socalled needle crystals (step 7) were precipitated after the rim cement was undercut and the fractures widened is obvious. However, no needle crystals have ever been found inside the intracrystalline pores and, theoretically, the latter could have been formed in the period between step 7 and step 10 (the anhydritization).

The original needle-like gypsum crystals, which are now converted into dolomite, were precipitated after the second phase of leaching (step 6) but before the anhydritization (step 10). Perhaps primary anhydrite, connected to the algal-rich areas of the rock (compare the tidal flat/sabkha model described by Shinn, 1983), was dissolved and reprecipitated as gypsum during the leaching phase (step 6). However, before the needle-crystals were precipitated the $\mathrm{Ca}-2$ carbonate must have been overlain by a thick mass of sediment as a phase of stylolitization occurred prior to the leaching. Therefore, in spite of the uplift/erosion the needle crystals must have been precipitated 
under a rather high pressure and temperature. This is noteworthy because gypsum is metastable even at relatively low temperatures. In normal seawater at atmospheric pressure the transition temperature at which anhydrite and gypsum are of equal solubility is only about $20^{\circ} \mathrm{C}$ (Krauskopf, 1979). The orginal gypsum in the present material must have been metastable. However, it is an open question why the original gypsum crystals were replaced by dolomite. After all, it is not absurd to imagine that the gypsum crystals were converted into the more stable (at higher pressure/temperature) anhydrite, and preserved as such until the present.

The dolomitization of the carbonate has probably occurred relatively very early in the diagenetic history as some well preserved coated grains (in subunit I and II), which have only been subjected to a faintly porphyroid neomorphism, consist solely, of dolomite.

Seepage-refluxion may have been the mechanism by which the dolomitization took place. The laterally (landward) adjacent or the overlying prograding evaporite (at the end of the Ca-2 tidal flat cycle) may have provided the sources of $\mathbf{M g}^{++}$-rich hypersaline solutions (Morrow, 1982). However, according to the mixed-water (or dilution) model a dolomitization could also have taken place under the influence of fresh groundwater after the sediments were buried to some depth (see below).

All the Ca-2 carbonate is converted into dolomite, no partly dolomitized intervals are seen as in the Ca-la unit of the Aabenraa-1 well. In the lower part of the latter a relatively late diagenetic dolomitization has probably taken place according to the burial-compaction model (Morrow, 1982).

The first phase of leaching (step 3) took place before the rock was subjected to a chemical compaction with formation of stylolites (step 4). It is likely that the numerous inter/intra-granular pores and moulds from gastropod shells are formed under the influence of freshwater. In regard to the rapid burial which occurred during Upper Zech- stein and Early Jurassic (fig. 29) the possible influx of freshwater must have influenced the rock relatively early in the diagenetic history. Where the fresh groundwater was later mixed with the phreatic saline seawater dolomitization might have occurred (according to the mixed-water model). So it is possible that the early dolomitization took place penecontemporaneously with the leaching. However, this is mere speculation. Freshwater has probably only played a very little part in the Zechstein period. Possibly the porosity has been generated as a result of an early transitory uplift to a level where vadose conditions prevailed.

The second phase of leaching (step 6) took definitely place after the stylolites were formed. Clark (1983) has made the same observation in Zechstein carbonates from several areas of NW Europe. According to Clark the carbonates of southern Denmark were affected by late-stage influxes of meteoric water that caused aggressive leaching when the rocks became exposed during the Triassic (Clark, 1980, p. 184 and fig. 19). From the subsidence curve of Løgumkloster-1 presented in this paper (fig. 29), which practically has the same configuration as that of Aabenraa-1 (cf. fig. 1), it seems unlikely that a tectonic uplift of such dimension has occurred in this area, even in Jurassic time, after the stylolites with associated fractures were formed. It is more likely that this late-stage, very aggressive leaching took place in a rather deep, phreatic zone without any influence of meteoric water.

In accordance with the diagenetic model outlined in the present paper also Clark established that an anhydrite cementation occurred in leached stylolites in the $\mathrm{Z} 1$ carbonate of southern Denmark, »demonstrating that anhydritization continued into the deep-burial phase of diagenesis « (Clark, 1983 , p. 183). However, according to clark the onset of anhydritization took place $b e$ fore the formation of stylolites. Texturally, that relationship has never been observed in thin sections in the present study (cf. fig. 16). That fractures may have played a part 
by facilitating the percolation of sulphatebearing solutions causing the anhydritization is also stated by Clark (Clark, 1983, p. 176). In the Ca-2 carbonate of Løgumkloster-1 only one generation of short fractures has been observed, and as many of the fractures terminate at the stylolite seams it is reasonable to assume that they are genetically related to the development of the stylolites (extension fractures derived from the same compressive state of stress as the stylolites, Nelson, 1979). For that reason it is tempting to oppose the diagenetic model of Clark by following reasoning: replacement of carbonate by anhydrite took partly place along fractures, fractures are associated to stylolites, consequently anhydritization took place after onset of stylolitization. However, it is not fair to make such a generalization. The argumentation does not fit, not even for the near-by Aabenraa-1 (fig. 1). In the basal part of Ca-1 of Aabenraa-1 the rock is thus intersected by three generations of fractures, and only one of these is associated to the stylolites. One generation predates the development of stylolites, these fractures are calcite-filled and the planes are oblique to the stylolite planes. Another generation of fractures postdates the stylolites. The planes of these fractures are parallel to the stylolite planes. They are not unloading fractures formed when the cores were taken as they are filled in with anhydrite and calcite cement (Stentoft \& Nygaard, 1985). However, in the Ca-1 carbonate of Aabenraa-1 the anhydritization certainly occurred after the stylolitization as for the Ca-2 carbonates of Løgumkloster-1 and Brøns-1. 


\section{Synthesis}

The Ca-2 rock of Løgumkloster-1 is primarily built up of coated grains, which descriptively can be divided into ooids and oncoids (»eggs« and "nodules") representing oolitic shoals and lagoonal deposits respectively (fig. 4).

Since deposition these sediments have experienced a complex diagenetic history resulting in the present complexity of the pore geometry and great variation of the porosity/permeability values (fig. 10). A total of 15 diagenetic events has been depicted. The reservoir quality of the rock is primarily linked to four events: two leaching phases, a phase of chemical compaction, and a late anhydritization. The cartoon of figure 30 shows how the rock typically, step by step, was affected by these events. The original sediment is shown in figure $30 \mathrm{~A}$. It consists of a lot of coated grains surrounded by mud. The primary, intergranular porosity is shown too. Shelter porosity is seen in connection with the gastropod shell. After an early lithification - and probably also do- lomitization - the rock was subjected to a leaching - leaching phase I (figure $30 \mathrm{~B}$ ). Inter- as well as intra-grain porosity was developed and a mould from the gastropod shell was formed. After the rock was buried to an adequate depth - more than 300 metres probably - a chemical compaction occurred (figure $30 \mathrm{C}$ ). Stylolites with associated fractures developed. Released carbonate was precipitated as rim cement around the coated grains, and perhaps also inside the intra-grain pores at the same time. Afterwards a renewed leaching took place - leaching phase II (figure $30 \mathrm{D}$ ). It resulted in a widening of the preexisting fractures and vugs, and probably also in the formation of intra-crystalline pores (inside the dolomite cement). This leaching cleared the road for the anhydritization which had the most negative effect on the reservoir quality (figure $30 \mathrm{E}$ ). From the fractures the anhydrite has spread in all directions, partly replacing the dolomite and filling in the cavities. 

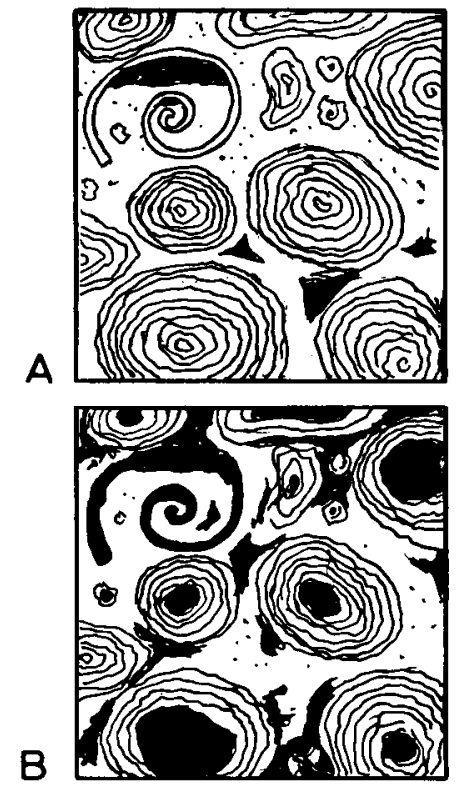

C

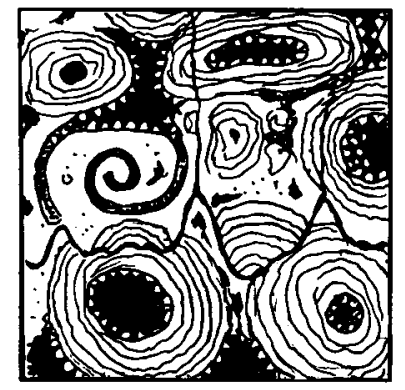

D
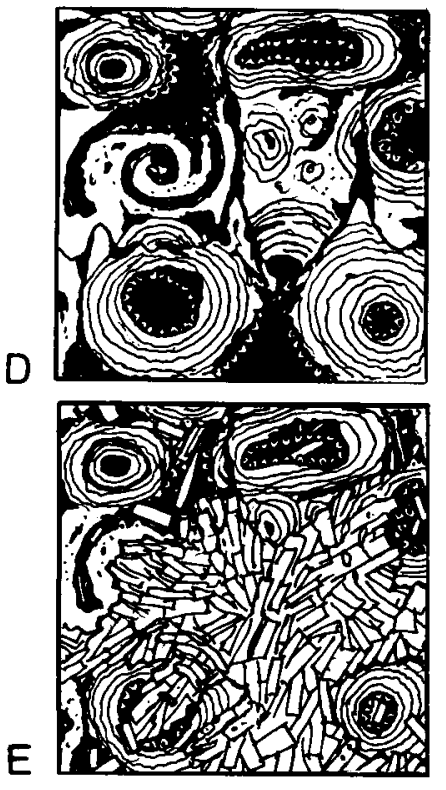

$D=$ ooid

$\not<=$ waterfilled pores

$\infty \infty^{\infty}=$ dolomite rim-cement crystals

= anhydrite crystals
Fig. 30: A schematic outline showing how the Ca-2 rock was affected step by step by the four most important diagenetic events (see the text). 


\section{Acknowledgements}

The author is indepted to $\mathrm{H}$. Zetterwall who made the drawings and to R.G. Bromley who kindly improved the English text. 


\section{References}

Bathurst, R.G.C., 1976: Carbonate sediments and their diagenesis. Developments in Sedimentology 12, Elsevier Scientific Publishing Company, Amsterdam Oxford New York, 658 pp.

Bögli, A., 1978: Karsthydrographie und physische Speläologie. Springer-Verlag, Berlin Heidelberg New York, 292 pp.

Clark, D.N., 1980: The diagenesis of Zechstein carbonate sediments. Contr. Sedimentology, 9, p. 167-203.

Clark, D.N. \& Tallbacka, L., 1980: The Zechstein deposits of southern Denmark. Contr. Sedimentology, 9, p. 205-231.

Dickson, J.A.D, 1965: A modified staining technique for carbonate in thin section. Nature, Vol. 205, No. 4971, p. 587.

Dunham, R.J., 1962: Classification of carbonate rocks according to depositional texture. Mem. Amer. Ass. Petrol. Geol., 1, p. 108-121.

Flügel, E., 1978: Mikrofazielle Untersuchungsmethoden von Kalken. Springer-Verlag, Berlin Heidelberg New York, 454 pp.

Folk, R.L., 1965: Some aspects of recrystallization in ancient limestones. SEPM, Special Publication no. 13, p. 14-48.

Füchtbauer, H., 1980: Composition and diagenesis of a stromatolitic bryozoan bioherm in the Zechstein 1 (northwestern Germany). Contr. Sedimentology, 9, p. 233-251.

Harland, W.B., Cox, A.V., Llewellyn, P.G., Pickton, C.A.G., Smith, A.G. \& Walters, R., 1982: A geologic time scale. Cambridge Earth Science Series, Cambridge University Press, Cambridge, 131 pp.

Herrmann, A., 1956: Der Zechstein am südwestlichen Harzrand. Geol. Jb., 72, p. 1-72.

Johnson, J.H., 1963: Pennsylvanian and Permian Algae. Quarterly of the Colorado School of Mines, Vol. 58, no. 3, p. 1-211.

Krauskopf, K.B., 1979: Introduction to Geochemistry, (International Student Edition). McGrawHill Kogakuska, Ltd., 617 pp.

Logan, B.W., Rezak, R. \& Ginsburg, R.N., 1964: Classification and environmental significance of algal stromatolites. Jour. Geology Vol. 72, p. 68-83.
Maiklem, W.R., Bebout, D.G. \& Glaister, R.P., 1969: Classification of anhydrite - a practical approach. Bulletin of Canadian Petroleum Geology, 17 (2), p. 194-233.

Morrow, D.W., 1982: Dolomitization models and ancient dolostones. Geoscience Canada, 9 (2), p. 95-107.

Nelson, R.A., 1979: Natural fracture systems, description and classification. AAPG Bull., Vol. 63 p. 2214-2221.

Peryt, T.M., 1983: Classification of coated grains. In: T.M. Peryt (Editor), Coated Grains. SpringerVerlag, Berlin Heidelberg New York Tokyo, p. 3-6.

Peryt, T.M. \& Peryt, D., 1975: Association of sessile tubular foraminifera and cyanophytic algae. Geol. Mag., Vol. 112, no. 6, p. 612-614.

Pettijohn, F.J., 1957: Sedimentary rocks. Harper \& Brothers, New York, 718 pp.

Philipsborn, H. von, 1967: Tafeln zum Bestimmen der Minerale nach äusseren Kennzeichen. E. Schweizerbart'sche Verlagsbuchhandlung, Stuttgart, 319 pp.

Randazzo, A.F. \& Zachos, L.G., 1984: Classification and description of dolomite fabrics of rocks from the Floridan aquifer, USA. Sedimentary Geology, 37, p. 151-162.

Rasmussen, L.B., 1978: Geological aspects of the Danish North Sea sector. Danm. Geol. Unders., Serie III, no. 44, 85 pp.

Richter, D.K., 1983a: Classification of coated grains: discussion. In: T.M. Peryt (Editor), Coated Grains. Springer-Verlag, Berlin Heidelberg New York Tokyo, p. 7-8.

Richter, D.K., 1983b: Calcareous ooids: A synopsis In: T.M. Peryt (Editor), Coated Grains. SpringerVerlag, Berlin Heidelberg New York Tokyo, p. 71-99.

Richter-Bernburg, G., 1955: Stratigraphische Gliederung des deutschen Zechsteins. Z. dt. Geol. Ges., Bd. 105, p. 843-854.

Shinn, E.A., 1983: Tidal flat environment. In: A. Scholle et al. (Editors), Carbonate Depositional Environments, AAPG Memoir 33, Tulsa, p. 171210. 
Stemmerik, L., Frykman, P., Christensen, O.W. \& Stentoft, N., 1987: The Zechstein carbonate of southern Jylland, Denmark. In: J. Brooks \& K. Glennie (Editors), Petroleum Geology of North West Europe. Graham \& Trotman, p. 365-374.

Stemmerik, L., Frykman, P. \& Stentoft, N., 1986: Depositional environment, diagenesis and stratigraphy of Zechstein carbonates. Danm. geol. Unders. internal report no. 23.
Stentoft, N. \& Nygaard, E., 1985 On the sedimentology and diagenesis of the basal Zechstein carbonate unit in the Aabenraa-1 well, Denmark. Danm. geol. Unders. internal report no. 11.

Tröger, W.E., 1971: Optische Bestimmung der gesteinbildenden Minerale. E. Schweizerbart'sche Verlagsbuchhandlung, Stuttgart, $188 \mathrm{pp}$. 
The Zechstein Ca-2 rock from the Løgumkloster-1 well is built up of coated dolomite grains, which descriptively can be divided into ooids and oncoids representing oolitic shoals and lagoonal deposits respectively.

Since deposition these sediments have experienced a remarkable complex diagenetic history resulting in the present complexity of the pore geometry and great variation of the porosity/permeability values. A total of 15 diagenetic events has been depicted. The reservoir quality of the rock is primarily linked to four of these events: two leaching phases, a phase of chemical compaction, and a late anhydritization. 